\title{
A Transient Developmental Window of Fast-Spiking Interneuron Dysfunction in a Mouse Model of Dravet Syndrome
}

\author{
Morgana Favero, ${ }^{1}$ Nathaniel P. Sotuyo, ${ }^{2}$ Emily Lopez, ${ }^{3}{ }^{\oplus}$ Jennifer A. Kearney, ${ }^{4}$ and ${ }^{-E}$ Ethan M. Goldberg ${ }^{1,2,5}$ \\ ${ }^{1}$ Division of Neurology, Department of Pediatrics, The Children's Hospital of Philadelphia, 19104 Philadelphia, Pennsylvania, ${ }^{2}$ Department of Neuroscience, \\ The Perelman School of Medicine at The University of Pennsylvania, 19104 Philadelphia, Pennsylvania, ${ }^{3}$ College of Arts and Sciences, The University of \\ Pennsylvania, 19104 Philadelphia, Pennsylvania, ${ }^{4}$ Department of Pharmacology, Northwestern University Feinberg School of Medicine, 60611 Chicago, \\ Illinois, and ${ }^{5}$ Department of Neurology, The Perelman School of Medicine at The University of Pennsylvania, 19104 Philadelphia, Pennsylvania
}

Dravet syndrome is a severe, childhood-onset epilepsy largely due to heterozygous loss-of-function mutation of the gene SCN1A, which encodes the type 1 neuronal voltage-gated sodium $\left(\mathrm{Na}^{+}\right)$channel $\alpha$ subunit Nav1.1. Prior studies in mouse models of Dravet syndrome $\left(\mathrm{Scnla}{ }^{+/-}\right.$mice) indicate that, in cerebral cortex, Navl.1 is predominantly expressed in GABAergic interneurons, in particular in parvalbumin-positive fast-spiking basket cell interneurons (PVINs). This has led to a model of Dravet syndrome pathogenesis in which Nav1.1 mutation leads to preferential dysfunction of interneurons, decreased synaptic inhibition, hyperexcitability, and epilepsy. However, such studies have been implemented at early developmental time points. Here, we performed electrophysiological recordings in acute brain slices prepared from male and female $S \mathrm{cn} 1 a^{+l-}$ mice as well as age-matched wild-type littermate controls and found that, later in development, the excitability of PVINs had normalized. Analysis of action potential waveforms indirectly suggests a reorganization of axonal $\mathrm{Na}^{+}$channels in PVINs from Scn1a ${ }^{+/-}$mice, a finding supported by immunohistochemical data showing elongation of the axon initial segment. Our results imply that transient impairment of action potential generation by PVINs may contribute to the initial appearance of epilepsy, but is not the mechanism of ongoing, chronic epilepsy in Dravet syndrome.

Key words: Dravet syndrome; epilepsy; fast-spiking interneurons; interneurons; Nav1.1; SCN1A

Significance Statement

Dravet syndrome is characterized by normal early development, temperature-sensitive seizures in infancy, progression to treatment-resistant epilepsy, developmental delay, autism, and sudden unexplained death due to mutation in SCN1A encoding the $\mathrm{Na}+$ channel subunit Nav1.1. Prior work has revealed a preferential impact of Nav1.1 loss on the function of GABAergic inhibitory interneurons. However, such data derive exclusively from recordings of neurons in young Scn1a ${ }^{+/-}$mice. Here, we show that impaired action potential generation observed in parvalbumin-positive fast-spiking interneurons (PVINs) in Scn1a $+/-$ mice during early development has normalized by postnatal day 35 . This work suggests that a transient impairment of PVINs contributes to epilepsy onset, but is not the mechanism of ongoing, chronic epilepsy in Dravet syndrome.

\section{Introduction}

Voltage-gated sodium $\left(\mathrm{Na}^{+}\right)$channels mediate the generation and propagation of electrical signals in excitable tissues, includ-

Received Jan. 3, 2018; revised July 12, 2018; accepted July 17, 2018.

Author contributions: E.M.G. designed research; M.F., N.P.S., E.L., and E.M.G. performed research; J.A.K. contributed unpublished reagents/analytic tools; M.F., N.P.S., E.L., and E.M.G. analyzed data; E.M.G. wrote the paper.

This work was supported by the National Institute of Neurological Disorders and Stroke-National Institutes of Health (Grant R01 NS084959 to J.A.K. and Grant K08 NS097633 to E.M.G.) and by Burroughs Wellcome (Fund Career Award for Medical Scientists to E.M.G.). We thank Xiaohong Zhang for expert technical assistance; Caroline Casey for assistance with immunohistochemistry; Hajime Takano for assistance with confocal microscopy; Marc V. Fuccillo, Eric D. Marsh, and Kevin M. Goff for critical reading of a prior version of the manuscript; and the Allen Institute for making available the Ai14 mouse line used in this study. ing in the central and peripheral nervous system and in muscle (Catterall, 2000, 2012; O'Malley and Isom, 2015). $\mathrm{Na}^{+}$channel complexes are composed of an $\alpha$ (pore-forming) subunit and an auxiliary $\beta$ subunit. Heterozygous loss-of-function mutation of SCN1A encoding the type 1 voltage-gated $\mathrm{Na}^{+}$channel $\alpha$ subunit Nav1.1 is the major cause of Dravet syndrome (severe myoclonic

\footnotetext{
The authors declare no competing financial interests.
}

Correspondence should be addressed to Dr. Ethan M. Goldberg, Assistant Professor, Division of Neurology, The Children's Hospital of Philadelphia, Abramson Research Center, Room 502A, 3501 Civic Center Boulevard, Philadelphia, PA 19104. E-mail: goldberge@email.chop.edu.

DOI:10.1523/JNEUROSCI.0193-18.2018

Copyright $\odot 2018$ the authors $\quad 0270-6474 / 18 / 387912-16 \$ 15.00 / 0$ 
epilepsy of infancy) (Claes et al., 2001), a childhood epilepsy syndrome characterized by normal or near-normal early childhood development, temperature-sensitive seizures in infancy evolving to treatment-resistant epilepsy with multiple seizure types, frequent status epilepticus, developmental delay/intellectual disability, ataxia, autism spectrum disorder, and an increased incidence of sudden death (SUDEP) (Dravet, 2011; Scheffer, 2012; Kalume et al., 2013).

Experimental models of Dravet syndrome, including mice with loss of Nav1.1 function $\left(\mathrm{Scn} 1 a^{+-}\right.$mice via deletion of part or all of the Scnla gene or targeted knock-in of Scnla point mutations), as well as induced pluripotent stem cell (iPSC)-derived neurons from patients with Dravet syndrome, have provided insight into disease pathogenesis. Scn1a ${ }^{+/-}$mice recapitulate salient features of the human syndrome and have been used to investigate the underlying cellular and circuit basis of the disease (Yu et al., 2006; Ogiwara et al., 2007; Miller et al., 2014; Mistry et al., 2014). This work implicates dysfunction of cerebral cortical GABAergic interneurons, and, more specifically, parvalbumin (PV)-expressing fast-spiking basket cell interneurons (PVINs) in Dravet syndrome pathogenesis. PVINs in neocortex and hippocampus are known to prominently express Nav1.1 at the proximal axon initial segment (AIS) (Lorincz and Nusser, 2008; Ogiwara et al., 2012; Hu and Jonas, 2014; Li et al., 2014) and are thought to preferentially rely on Nav1.1 for action potential (AP) generation. Loss of Nav1.1 in interneurons is hypothesized to precipitate interneuron dysfunction, network hyperexcitability, and seizures.

With the initial descriptions of Scnla ${ }^{+/-}$mice, electrophysiological recordings from acutely dissociated hippocampal neurons from postnatal day 13 (P13)-P14 mice revealed decreased $\mathrm{Na}^{+}$current in bipolar-appearing cells immunopositive for the glutamic acid decarboxylase $67 \mathrm{kDa}$ isoform $\left(\mathrm{GAD}_{67}\right)$, but not in pyramidal cells, in homozygous mutant mice on a C57BL/6J background relative to controls (Yu et al., 2006). Consistent with this, whole-cell recordings performed in visual cortex in acute brain slices prepared from heterozygous $S c n 1 a^{+/-}$mice revealed impaired excitability, impaired high-frequency firing, and a progressive decrement in AP amplitude during repetitive firing, in PVINs of $S \mathrm{cnla} \mathrm{a}^{+/-}$mice, whereas pyramidal neurons exhibited normal properties (Ogiwara et al., 2007).

Subsequent studies in $\mathrm{Scnla}^{+/-}$mice showed impaired excitability of interneurons immunopositive for the neuropeptide somatostatin (SST; SST-INs), although to a lesser extent than that seen in PVINs (Tai et al., 2014). Conditional deletion of Scn1a from Dlx $1 / 2^{+}$medial ganglionic eminence (MGE) progenitors, which generate PVINs and SST-INs (Wonders and Anderson, 2006), reproduced the phenotype of the global mutant (Cheah et al., 2012), including temperature-sensitive seizures, epilepsy, and spontaneous death, suggesting that loss of Scnla in MGE progenitors is sufficient to generate the Dravet syndrome-like phenotype. Interestingly, the initial description showed immunohistochemical evidence of upregulation of Nav1.3 in $\mathrm{GAD}^{+}$neurons in Scnla-null mice and, to some extent, in Scnla ${ }^{+/-}$heterozygotes, in hippocampus, but not in neocortex (Yu et al., 2006). Mistry et al. (2014) showed reduced $\mathrm{Na}^{+}$current density in bipolar interneurons from acutely dissociated mouse hippocampus from Scn1a ${ }^{+/-}$mice at P21-P24 on a mixed C57BL/6J:129S6 background, but not on a pure $129 \mathrm{~S} 6$ background; $\mathrm{Na}^{+}$current density was increased in pyramidal cells on both backgrounds (Mistry et al., 2014). Such data suggest that loss of one copy of Scnla may be accompanied by compensatory changes in or upregulation of neuronal $\mathrm{Na}^{+}$currents in interneurons and/or principal cells.
Neurons generated from patient-derived iPSCs provide another model of Dravet syndrome, although the ability to generate PVINs from human stem cells remains limited (Nicholas et al., 2013; Sun et al., 2016a) and results as to the relative impact of loss of SCN1A on interneurons versus excitatory cells has been variable (Higurashi et al., 2013; Jiao et al., 2013; Liu et al., 2013; Sun et al., 2016b). In an early study of iPSC-derived neurons from two different patients with Dravet syndrome, pyramidal neurons as well as bipolar neurons expressing various immunohistochemical interneuron markers showed increased excitability and increased $\mathrm{Na}^{+}$current density relative to iPSC-derived neurons from normal controls (Liu et al., 2013). A more recent study showed decreased excitability and $\mathrm{Na}^{+}$current density in MGEderived interneuron-like cells, but not excitatory neurons, in iPSC-derived neurons from a patient with Dravet syndrome relative to control (Sun et al., 2016b), although $\mathrm{PV}^{+}$cells were not generated.

Here, we performed targeted whole-cell recordings from identified pyramidal neurons and confirmed PVINs at $30-32^{\circ} \mathrm{C}$ in acute brain slices of primary somatosensory cortex from male and female $S \mathrm{cnla} \mathrm{a}^{+/-}$mice and age-matched wild-type littermate controls on a strict 50:50 mixed C57BL/6J:129S6 background (Mistry et al., 2014) across development to determine the maturational profile of PVINs in Scn1a $a^{+/-}$mice. We show that PVINs exhibit prominent yet transient impairment of AP generation specifically in a delimited time window in the second and third postnatal weeks (P11-P21), with subsequent normalization of excitability by P35. We propose that dysfunction of PVINs contributes to the appearance of epilepsy, but is not the long-term mechanism of ongoing, chronic epilepsy in Dravet syndrome.

\section{Materials and Methods}

Mice. All experiments were conducted in accordance with the ethical guidelines of the National Institutes of Health and with approval of the Institutional Animal Care and Use Committee of The Children's Hospital of Philadelphia. Mice were weaned at P22 and were group housed in cages holding between two and five mice on a $12 \mathrm{~h}$ light/dark cycle with access to food and water ad libitum. Experiments were performed using both male and female mice in approximately equal ratios.

Mouse strains used for this study included the following: wild-type 129S6.SvEvTac (Taconic Biosciences model \#129SVE; RRID:IMSR_TAC: 129sve), wild-type C57BL/6J (RRID:IMSR_JAX:000664), Scn1a ${ }^{+\prime}$ mice on an 129S6.SvEvTac background (RRID:MMRRC_037107-JAX; these mice harbor a targeted deletion of the first exon of the mouse Scn 1a gene that leads to absence of Nav1.1 protein Miller et al., 2014; Mistry et al., 2014), PV-Cre mice expressing Cre recombinase in all $\mathrm{PV}^{+}$cerebral cortical GABAergic interneurons (B6;129P2-Pvalbtm1(cre)Arbr/J; RRID:IMSR_JAX:008069), and tdTomato reporter/Ai14 mice (RosaCAG-LSL-tdTomato; RRID:IMSR_JAX:007914; congenic on a $100 \%$ C57BL/6J background) (Madisen et al., 2010). All mice used for experiments were on a strictly maintained 50:50 129S6:C57BL/6J mixed background, the phenotype of which has been well characterized (Miller et al., 2014; Mistry et al., 2014; Anderson et al., 2017; Hawkins et al., 2017) and closely resembles human Dravet syndrome clinically. The breeding strategy used to generate mice in which tdTomato is expressed in PVINs in Scn $1 a^{+/-}$mice and wild-type littermate controls is depicted in Figure 1. Homozygous PV-Cre mice were crossed to homozygous Rosa.LSLtdTomato mice to generate PV-Cre.tdT double heterozygotes on a $100 \%$ C57BL/6J background. Female PV-Cre.tdT double heterozygotes are then crossed to male $129 \mathrm{~S} 6 . \mathrm{Scn} 1 a^{+/-}$mice to generate Scn1a.PVCre.tdT mice and wild-type PV-Cre.tdT littermate controls. Genotype of all mice was determined via PCR analysis of a tail snip obtained at P7 and was confirmed for each mouse after they were killed for slice preparation. There were no genotyping errors.

Acute brain slice preparation. Parasagittal slices were prepared from P10, P11-P12, P18-P21, or P35-P56 mice of both genotypes. Mice were 
anesthetized with isoflurane and decapitated. The brain was removed to ice-cold artificial CSF (ACSF), the cerebellum was removed, the hemispheres separated with a scalpel, and the brain was glued to the specimen holder of a Leica VT-1200S vibratome with cyanoacrylate glue. Slices were cut in ice-cold ACSF composed of the following (in $\mathrm{mM}$ ): $\mathrm{NaCl}, 87$; sucrose, 75; KCl, 2.5; $\mathrm{CaCl}_{2}, 1.0 ; \mathrm{MgSO}_{4}, 2.0 ; \mathrm{NaHCO}_{3}, 26 ; \mathrm{NaH}_{2} \mathrm{PO}_{4}$, 1.25; glucose, 10. ACSF was maintained at a $\mathrm{pH}$ of $7.30-7.40$ via continuous equilibration with carbogen $\left(95 \% \mathrm{O}_{2}, 5 \% \mathrm{CO}_{2}\right)$. Slices were allowed to recover for $30 \mathrm{~min}$ at $32^{\circ}$ in cutting solution and then maintained at room temperature before transfer to a submersion-type recording chamber on the stage of a BX-61 upright microscope, at which time slices where perfused with recording solution at $30-32^{\circ} \mathrm{C}$ at $3-4 \mathrm{ml} / \mathrm{min}$. Slices were maintained in the holding chamber for up to $6 \mathrm{~h}$ before recording, after which time they were discarded. Recording solution contained the following (in mM): $\mathrm{NaCl}, 125 ; \mathrm{KCl}, 2.5 ; \mathrm{CaCl}_{2}, 2.0 ; \mathrm{MgSO}_{4}, 1.0 ; \mathrm{NaHCO}_{3}$, 26; $\mathrm{NaH}_{2} \mathrm{PO}_{4}, 1.25$; glucose, 10.

Electrophysiology. PVINs were identified via endogenous tdTomato expression as visualized with epifluorescence microscopy. Pyramidal cells were targeted based on pyramidal morphology under infrared differential interference contrast microscopy and were confirmed to be tdTomato negative. Whole-cell recordings were obtained from neurons in layer $2 / 3$ primary somatosensory neocortex ("barrel" cortex) with patch pipettes pulled from borosilicate glass (outer diameter, $1.5 \mathrm{~mm}$; inner diameter, $0.86 \mathrm{~mm}$ ) pulled on a horizontal puller (P-97; Sutter Instruments) and filled with intracellular solution that contained the following (in mM): K-gluconate, 130; $\mathrm{KCl}$, 6.3; EGTA, 0.5; $\mathrm{MgCl}_{2}$, 1.0; HEPES, 10; Mg-ATP, 4.0; Na-GTP, 0.3.pH was adjusted to 7.30 with $\mathrm{KOH}$; osmolarity was adjusted to $285 \mathrm{mOsm}$ with $30 \%$ sucrose. When filled with internal solution, pipettes had a resistance of 5-7 M $\Omega$. Calculated chloride equilibrium potential was $-70 \mathrm{mV}$. In a subset of experiments, intracellular solution contained $50 \mathrm{~mm}$ Alexa Fluor 488 hydrazide (A10436; Thermo Fisher Scientific) and/or 0.5\% neurobiotin (SP1120; Vector Laboratories). Unless otherwise specified, chemicals were from Sigma-Aldrich).

Current-clamp recordings were performed with a MultiClamp 700B amplifier (Molecular Devices) using pCLAMP 10 software. Cells with resting membrane potentials more positive than $-55 \mathrm{mV}$ or for which access resistance increased by $>20 \%$ during serial monitoring throughout the recording were discarded. Pipette capacitance and series resistance compensation (bridge balance) were applied throughout current-clamp experiments, with minor bridge balance readjustments allowed as required. Signals were low-pass filtered at $10 \mathrm{kHz}$, sampled at $50-100 \mathrm{kHz}$, and digitized using a Digidata 1550A 16-bit D/A converter (Molecular Devices). Reported values for membrane potential $\left(V_{\mathrm{m}}\right)$ and AP threshold are not corrected for the liquid junction potential, which was calculated as $16.3 \mathrm{mV}$ at $32^{\circ} \mathrm{C}$.

Immunohistochemistry. Mice were deeply anesthetized with isoflurane, transcardially perfused with $20-30 \mathrm{ml}$ of cold $0.1 \mathrm{M}$ PBS, and then with 20 $\mathrm{ml}$ of cold $0.1 \mathrm{M}$ PBS with $1 \%$ formaldehyde and $0.5 \%$ methanol to preserve the AIS (Alshammari et al., 2016). Brains were carefully removed from the skull and postfixed in $0.1 \mathrm{~m}$ PBS with $1 \%$ formaldehyde and $0.5 \%$ methanol for $1 \mathrm{~h}$ and then transferred to glass vials containing $30 \%$ sucrose for $1-2 \mathrm{~d}$ at $4^{\circ} \mathrm{C}$ until samples sank to the bottom of the vial. Brains were embedded in optimal cutting temperature compound (Sakura Finetek), sectioned at $16 \mu \mathrm{m}$ on a cryostat, mounted on glass slides, and stored at $-80^{\circ} \mathrm{C}$ until being used for histochemistry. Slides were dried at $37^{\circ} \mathrm{C}$, washed in PBS, treated with cold acetone, washed again in PBS, and then blocked and permeabilized with $10 \%$ normal goat serum and $0.3 \%$ Triton X-100 for $1 \mathrm{~h}$. Tissue was then incubated overnight at $4^{\circ} \mathrm{C}$ in $\mathrm{PBS}$ with $3 \%$ BSA along with primary antibodies mouse IgG2a anti-ankyrin-G (NeuroMabs) and mouse IgG1 anti-PV (Millipore). The following day, sections were washed in PBS and then incubated in PBS with 3\% BSA and 1\% Tween with secondary antibodies Alexa Fluor 488-conjugated goat anti-mouse IgG2a and Alexa Fluor 568conjugated goat anti-mouse IgG1. After washing, slides were coverslipped and sealed before imaging on a Leica TCS SP8 confocal microscope. Tissue from all four groups (wild-type and Scnla ${ }^{+/-}$at P18-P21 and P35-P56) was processed in parallel and images were obtained and data quantified blinded to genotype.
For cell visualization after recording, slices were fixed in $0.1 \mathrm{M}$ PBS containing $4 \%$ paraformaldehyde overnight and stored in PBS. Neurobiotin was labeled using Alexa Fluor 488-conjugated streptavidin (Invitrogen), mounted on a glass slide, and imaged. Neurons were defined as multipolar based on the presence of multiple primary processes emanating from the soma, a dense local axonal arborization around the parent cell body, absence of an apical dendrite, and absence of dendritic spines (Defelipe et al., 2013).

Analysis of electrophysiology data. Analysis was performed blinded to genotype with custom-written scripts in MATLAB (The MathWorks), with manual confirmation as necessary using the Clampfit module of pCLAMP.

Spontaneous resting membrane potential $\left(V_{\mathrm{m}}\right)$ was determined $2 \mathrm{~min}$ after break-in as the average membrane potential during a $1 \mathrm{~s}$ sweep with no current injection. Input resistance $\left(R_{\mathrm{m}}\right)$ was calculated as the slope of the linear fit to the plot of the $V-I$ relation derived from small subthreshold current steps at/around resting membrane potential. AP amplitude/ height was calculated from AP threshold \#1 (see below) to the absolute value of the peak of the AP for the first spike obtained at the lowest current amplitude that elicited sustained firing

AP threshold was calculated via two methods (Naundorf et al., 2006; Meeks and Mennerick, 2007; Shu et al., 2007; Kress et al., 2008). The first method (AP threshold \#1) defined threshold as the voltage at which the first derivative $(\mathrm{d} V / \mathrm{dt})$ of the AP waveform reached $10 \mathrm{mV} / \mathrm{ms}$; the second method (AP threshold \#2) defined threshold as the voltage at which the second derivative $\left(\mathrm{d}^{2} V / \mathrm{dt}^{2}\right)$ was $5 \%$ of its maximum value. These methods typically yielded similar values (see Tables 3,5 ).

Rheobase was defined as the current step that first elicited at least one AP. Once rheobase was established via ascending 25-100 pA current steps, smaller (2-10 pA) steps were tested at/around rheobase to more accurately determine this value. AP rise time is the time from AP threshold to the peak of the AP for the first spike obtained at suprathreshold current injection. AP half-width (AP $1 / 2$-width) is defined as the width of the AP (in ms) at half-maximal amplitude, calculated using AP threshold $\# 1$ and the peak of the AP. AP afterhyperpolarization (AHP) amplitude is calculated as the depth of the afterdischarge potential (in millivolts) relative to AP threshold.

Spike-frequency adaptation (SFA) is calculated as the ratio of the first to the tenth $\left(I S I_{1} / I S I_{10}\right)$ and the ratio of the first to the last $\left(I S I_{1} / I S I_{n}\right)$ interspike interval for the first suprathreshold current injection that elicited sustained, tonic firing. Maximal steady-state firing frequency is the maximal mean firing frequency in response to a current injection at which there are no AP failures, with spikes defined as having a clear AP threshold as per above, amplitude of $40 \mathrm{mV}$ or higher, and overshooting $-10 \mathrm{mV}$. Maximal instantaneous firing frequency is the inverse of the smallest interspike interval at maximal current step injection.

Phase plots were generated using the membrane potential trace and the $\mathrm{d} V / \mathrm{dt}$ trace. Inflection rate was calculated as the slope of the phase plot at AP threshold (Naundorf et al., 2006; Shu et al., 2007; Kress et al., 2008). Stationary inflection was defined by a "double bump" in the $\mathrm{d}^{2} V /$ $\mathrm{dt}^{2}$ curve combined with a local value of equal to or less than zero of the $\mathrm{d}^{3} \mathrm{~V} / \mathrm{dt}^{3}$ trace; that is, a slope of zero of the $\mathrm{d}^{2} \mathrm{~V} / \mathrm{dt}^{2}$ trace indicating clear temporal resolution of the somatic and axonal components of the AP (Kress et al., 2008).

Experimental design and statistical analysis. Data from 75 mice were included in the study: 8 wild-type and $16 \mathrm{Scn}_{1} a^{+/-}$from P10-P12; 11

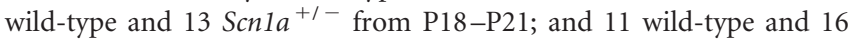
Scn1a ${ }^{+1-}$ from P35-P36. This included recordings from a total of 159 PVINs (24 wild-type and $34 S_{c n} 1 a^{+/-}$at P10-P12; 26 wild-type and 23 Scn1a $a^{+/-}$at P18-P21; and 21 wild-type and 29 Scn1a $a^{+/-}$at P35-P56), and 46 pyramidal cells (10 wild-type and $10 S c n 1 a^{+/-}$at P18-P21; and

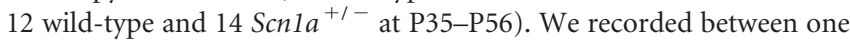
and five cells per mouse, obtaining two to four slices containing primary somatosensory cortex from each hemisphere, and recorded one to two cells per slice.

For statistical analysis, we used a population-averaged approach. For each outcome variable, a generalized estimating equation was used to test 
Table 1. Summary of previous studies of defined subsets of neurons in $\mathrm{Scn} 1 a^{+/-}$neurons

\begin{tabular}{|c|c|c|c|c|c|c|c|c|}
\hline Reference & Scn1a ${ }^{+/-}$mouse model & Genetic background & Age & Temperature $\left({ }^{\circ} \mathrm{C}\right)$ & Preparation & Brain area/layer(s) & Cell type(s) & Results (Scn1 $1 a^{+/-}$vs wild-type) \\
\hline Yu et al., 2006 & $\begin{array}{r}\text { Deletion of last exon (S3-6 } \\
\text { of DIV and C-terminus) }\end{array}$ & C57BL/6J (100\%) & P13-P14 & RT & Acutely dissociated cells & Hippocampus & Bipolar & $\begin{array}{l}\text { (1) } \uparrow A \mathrm{AP}^{1} / 2 \text {-width } \\
\text { (2) } \downarrow \mathrm{Na}+\text { current density } \\
\text { (3) } \downarrow \text { firing frequency } \\
\text { (4) } \downarrow \text { AP height, AHP amplitude } \\
\text { - }\end{array}$ \\
\hline Ogiwara et al., 2007 & Scn1ap.R1407X & $\begin{array}{l}\text { Mixed (57BL/6J: } 12956 \text { (75\%/ } \\
\quad 25 \%)\end{array}$ & P25-P29 & 25 & Acute brain slice & V1 & $\mathbb{I N}^{\mathrm{a}}$ & $\begin{array}{l}\text { (1) } \uparrow A P^{1} / 2 \text {-width } \\
\text { (2) } \uparrow A P \text { height accommodation } \\
\text { (3) } \downarrow R M P \text {, firing frequency } \\
\text { - }\end{array}$ \\
\hline Mistry et al., 2014 & Exon 1 deletion & $12956(100 \%)$ & P14-P24 & RT & Acutely dissociated cells & Hippocampus & $\begin{array}{l}\text { Bipolar } \\
\text { PC }\end{array}$ & $\begin{array}{l}\text { (1) } \uparrow I_{\text {Na }} \text { density at P21-P24 } \\
\text { (2) } \uparrow \text { firing frequency } \\
\text { (3) } \uparrow \text { spontaneous firing }\end{array}$ \\
\hline & & $\begin{array}{l}\text { Mixed C57BL/6): } 12956 \text { (50\%/ } \\
\quad 50 \%)\end{array}$ & P14-P24 & RT & Acutely dissociated cells & Hippocampus & $\begin{array}{l}\text { Bipolar } \\
\text { PC }\end{array}$ & $\begin{array}{l}\text { (1) } \downarrow I_{\mathrm{Na}} \text { density } \\
\text { (1) } \uparrow \mathrm{Na}+\text { current density at P21- } \\
\mathrm{P} 24^{\mathrm{b}} \\
\text { (2) } \uparrow \text { firing frequency, spontaneous } \\
\text { firing }\end{array}$ \\
\hline Tai et al., 2014 & as in Yu et al., 2006 & C57BL/6J (100\%) & P14-P22 & $22-24$ & Acute brain slice & Layer V S1BF & $\begin{array}{l}\text { PV IN } \\
\text { SST IN } \\
\text { PC }\end{array}$ & $\begin{array}{l}\text { (1) } \uparrow \text { rheobase, AP threshold } \\
\text { (2) } \downarrow \text { AP height, firing frequency } \\
\text { (1) } \uparrow \text { rheobase, AP threshold } \\
\text { (2) } \downarrow \text { firing frequency } \\
\text { - }\end{array}$ \\
\hline Hedrich et al., 2014 & Scn1ap.R1648 ${ }^{c}$ & C57BL/6J (100\%) & P14-P20 & $21-23$ & Acute brain slice & $\begin{array}{l}\text { L4S1BF } \\
\text { CA1 s.o. }\end{array}$ & $\begin{array}{l}\operatorname{PVIN}^{\mathrm{a}} \\
\operatorname{PVIN}^{\mathrm{a}}\end{array}$ & $\begin{array}{l}\text { (1) } \downarrow \text { firing frequency in } \mathrm{Scn} 1 a^{+/-} \text {mice } \\
\text { (1) } \downarrow \text { firing freqency, } I_{\mathrm{Na}} \text { in } \mathrm{SCn} 1 a^{+/-} \\
\text {mice } \\
\text { (2) }-\downarrow \text { firing frequency, } I_{\mathrm{Na}} \text { in } \\
\quad \operatorname{Scn} 1 a^{-/-} \text {mice } \\
\text { _ }\end{array}$ \\
\hline Rubinstein et al., 2015a & as in Yu et al., 2006 & $\begin{array}{l}\text { C57BL/6J (100\%) } \\
12956(100 \%)\end{array}$ & $\begin{array}{l}\text { P14-P16 and P21- } \\
\text { P24 }\end{array}$ & $\begin{array}{l}\text { RT } \\
\text { Acute brain slice }\end{array}$ & Dissociated cells & $\begin{array}{l}\text { Hippocampus } \\
\text { s.o. IN PC }\end{array}$ & $\begin{array}{l}\text { Bipolar } \\
\text { (2) } \downarrow \text { excitability of s.o. } \\
\text { INs but not PCs in B6 } \\
\text { DS but not } 12956 \\
\text { mice }\end{array}$ & $\begin{array}{l}\text { (1) } \downarrow I_{\mathrm{Na}} \text { in dissociated bipolar neurons } \\
\text { from B6 but not } 12956 \text { mice at P14- } \\
\text { P16 but not P21-P24 }\end{array}$ \\
\hline Tsai et al., 2015 & Scn1ap.E1099X & Mixed $^{d}$ & PW3-P4 & RT & Acute brain slice & DG & $\mathrm{PV}+\mathrm{IN}^{\mathrm{a}}$ & $\begin{array}{l}\text { (1) } \downarrow \text { firing frequency } \\
\text { (2) } \downarrow \text { AP amplitude, AHP amplitude } \\
\text { (3) } \uparrow \text { AP height accommodation, } 1 / 2 \text { - }\end{array}$ \\
\hline De Stasi et al., 2016 & as in Yu et al., 2006 & C57BL/6J or mixed ${ }^{e}$ & $\mathrm{P} 16-\mathrm{P} 18$ & $30-32$ & Acute brain slice & Neocortex layer II/III & $\begin{array}{l}\text { PVIN } \\
\text { SST IN } \\
\text { PC }\end{array}$ & $\begin{array}{l}\text { (1) } \downarrow \text { firing frequency, input resistance } \\
\text { (2) } \downarrow \text { firing frequency, AP } 1 / 2 \text {-width } \\
\text { - }\end{array}$ \\
\hline Present study & as in Mistry et al., 2014 & as in Mistry et al., 2014 & P18-P21 & $30-32$ & Acute brain slice & Neocortex layer II/III & $\begin{array}{l}\text { PC } \\
\text { PVIN } \\
P C\end{array}$ & $\begin{array}{l}\text { (1) } \downarrow \text { firing frequency, AP threshold } \\
\text { (2) } \uparrow \mathrm{AP}^{1} / \text { - }^{- \text {width }} \\
\text { (3) } \uparrow \mathrm{AP} \text { height accommodation } \\
\text { (4) } \uparrow R_{\mathrm{m}} ; \downarrow \text { rheobase } \\
- \\
- \\
\text { - }\end{array}$ \\
\hline
\end{tabular}

aPresumed PV IN from Gad1-GFP knock-in mice.

${ }^{\mathrm{b}}$ No difference versus wild-type at P13-P14.

'Mutation associated with Genetic Epilepsy with Febrile Seizures Plus (GEFS ${ }^{+}$).

${ }^{\mathrm{d}}$ C57BL/6JNarl:129S2/SvPasCrl.

etdTomato reporter strain Ai14 (Jackson Laboratories strain no. 007908) used in the study is on a mixed C57BL/6J:12956 background.

S1BF, Primary somatosensory/barrel cortex; s.0., stratum oriens; s.p., stratum pyramidale.

for a difference between genotypes within an age group or for a difference between two age groups within a given genotype as follows:

$$
y_{i j}=\beta_{0}+\beta_{1} G_{i}+\beta_{2} A_{i}^{(2)}+\beta_{3} A_{i}^{(3)}+\beta_{4} G_{i}^{(3)} X A_{i}^{(2)}+\beta_{5} G_{i}^{(3)} X A_{i}^{(3)}+\epsilon_{i j}
$$

where $y_{\mathrm{ij}}$ is the outcome of cell $j,\left(j=1, \ldots, m_{\mathrm{i}}\right)$ from animal $i,(i=1, \ldots$, $n), G_{\mathrm{i}}$ is the genotype indicator of animal $i$, and $A_{\mathrm{i}}^{(2)}$ and $A_{\mathrm{i}}^{(3)}$ are age group indicators.

We specified an exchangeable correlation structure to the model as follows:

$$
\operatorname{Cor}\left(\epsilon_{i j}, \epsilon_{i k}\right)=p, i=1, \ldots, n ; j, k=1, \ldots, m_{i} .
$$

to account for any effect of multiple measurements (cells) recorded from a given experimental animal. This accounts for between-cell variation, whereas the model specification itself (i.e., model terms) accounts for between-animal variation. Statistical significance was defined as $p<0.05$ via Wald test. Data were analyzed using R (The R Project for Statistical
Computing; RRID:SCR_001905). The models were fitted using the geeglm function from the geepack $R$ package.

\section{Results}

Differential developmental regulation of PVIN excitability in Scn $1 a^{+/-}$mice versus wild-type

Prior work in acutely dissociated cells and in brain slices prepared from $\mathrm{Scnla} \mathrm{a}^{+/-}$mice has shown specific dysfunction of defined subsets of cerebral cortical GABAergic inhibitory interneurons, particularly PVINs (Table 1). However, such recordings were performed using mice aged $\leq \mathrm{P} 29$, with most recordings being performed during the second and third postnatal weeks. PVINs are well known to undergo rapid developmental maturation of intrinsic electrophysiological and synaptic properties in the second through fourth postnatal weeks in mouse (Tansey et al., 2002; Chattopadhyaya et al., 2004; Goldberg et al., 2011; 
Pangratz-Fuehrer and Hestrin, 2011; Yang et al., 2014). The developmental status of the brain of a P21 mouse is considered most similar to a young (2- to 3 -year-old) human child (Semple et al., 2013; Dutta and Sengupta, 2016) and may not accurately reflect the maturational stage of all children with Dravet syndrome, particularly school-age children with chronic, established epilepsy and intellectual disability. To better define the trajectory of PVIN development in Scn $1 a^{+/-}$mice, we performed targeted whole-cell electrophysiological recordings from pyramidal cells and PVINs in layer $2 / 3$ primary somatosensory neocortex ("barrel cortex") in acute brain slices prepared from Scn $1 a^{+/-}$mice and agematched wild-type littermate controls expressing the red fluorescent protein (RFP) variant tdTomato (tdT) under PVspecific Cre-dependent control (Taniguchi et al., 2011) (Fig. 1). We selected this brain area/layer for the purposes of reproducibility because layer $2 / 3$ rodent barrel cortex is well characterized in terms of interneuron diversity, cellular neurophysiology, and synaptic connectivity, with multiple prior reports focusing on electrophysiological properties of PVINs in layer 2/3 barrel cortex in vitro and in vivo including across development.

The Scn $1 a^{+/-}$mice used here exhibited similar features to that reported in the published literature for this line across a range of parameters (Miller et al., 2014; Mistry et al., 2014; Anderson et al., 2017; Hawkins et al., 2017), including the presence of spontaneous and temperature-induced seizures and sudden death, along with hyperactivity and deficits in social behavior (Han et al., 2012; Rubinstein et al., 2015a). We found that the rate of sudden death in the Scn1a.PV-Cre.tdT used here was $25.1 \%$ ( 57 of 227 mice) by P56 in those mice not used for experiments before P56. We performed a separate, dedicated continuous video-monitoring study of $n=19$ Scn1a.PV-Cre.tdT mice from 8 litters and found the rate of sudden death to be $31.6 \%(6 / 19)$ by $\mathrm{P} 42$, which is similar to the value of $\sim 35 \%$ reported by Hawkins et al. (2017) for SUDEP rate by P42 in the same mouse line on the same genetic background used here, although maintained in a different laboratory at a separate institution.

Recordings at P18-P21 demonstrated abnormal intrinsic electrophysiological properties of PVINs consistent with decreased $\mathrm{Na}^{+}$current (Figs. 2B,E,J, 3, Tables 2, 3). PVINs in Scn $1 a^{+/-}$mice at P18-P21 exhibited impaired excitability, decreased ability to support sustained trains of APs at high frequency, marked spike height accommodation, and AP failures with repetitive firing in response to current injections of increasing amplitude (Fig. 2 B,E). PVINs in Scn $1 a^{+/-}$mice at P18-P21 displayed a markedly lower maximal instantaneous firing frequency as well as a lower maximal steady-state firing frequency before AP failure (Fig. 2B,E,J, Table 2). We also found that the degree of SFA in PVINs from Scn $1 a^{+/-}$at P18-P21 was greater than for agematched wild-type PVINs as measured by the ratio of the first to the tenth interspike interval $\left(\mathrm{ISI}_{1} / \mathrm{ISI}_{10}\right)$ for sustained trains of APs at/
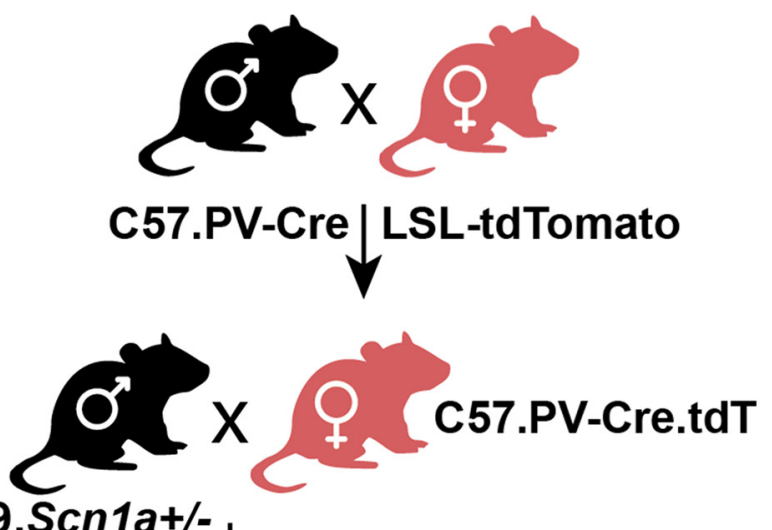

129.Scn1a+/-

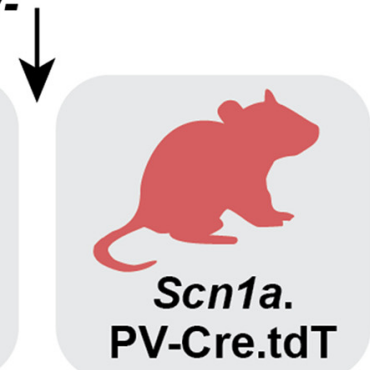

PV-Cre.tdT

PV-Cre.tdT

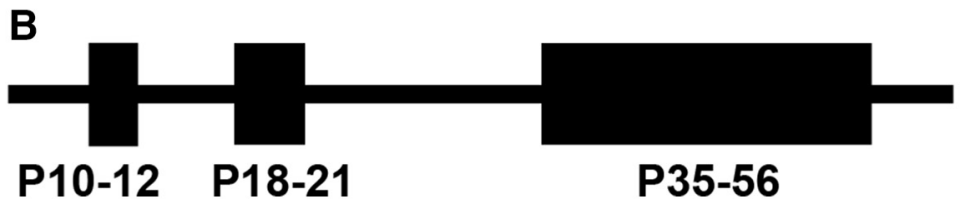

Figure 1. Breeding strategy to generate Scn1a.PV-Cre.tdTomato mice. A, Ai14 (Rosa.LSL-tdTomato) homozygous mice on a C57BL/6J background are bred with homozygous PV-Cre mice to produce interneuron-Cre.tdT double-heterozygous mice (F1). PV-Cre.tdT double-heterozygous mice are bred to $\mathrm{Scn} 1 a^{+/}$mice maintained on a $129 \mathrm{~S} 6$ background. Progeny (F2) include Scn1a.PV-Cre.tdT mice (1:8 predicted Mendelian ratio) and age-matched wild-type littermate controls (1/8). $\boldsymbol{B}$, Schematic of the developmental time points included in the study.

near rheobase current injection $\left(0.85 \pm 0.03\right.$ for $\operatorname{Scn} 1 a^{+/-}$vs $0.92 \pm$ 0.02 for wild-type; $p<0.05$ via Wald test; Table 2$)$.

We noted differences in the properties of individual APs between wild-type and Scn1a $a^{+/-}$mice at P18-P21 across multiple measurements (Table 3), including voltage threshold for AP generation as measured via two methods that yielded similar results (see Materials and Methods). AP height and amplitude of the fast, deep AHP characteristic of PVINs were identical between groups (Table 3), although there was spike height accommodation during sustained trains of APs in PVINs from Scnla ${ }^{+/-}$mice (Fig. 2B).

To better understand the developmental regulation of PVIN excitability in Scnla ${ }^{+/-}$mice, we performed similar recordings in acute brain slices prepared from heterozygous mutant and age-matched wild-type littermate controls during an earlier time window between P10 and P12. P10 was the earliest time point at which we could identify PVINs in the brain slice because tdTomato fluorescence could not be detected in brain slices prepared from PV-Cre.tdT mice before this, likely due to the developmental expression pattern of PV itself (de Lecea et al., 1995). In contrast to the striking differences between PVINs in wild-type and Scn1a ${ }^{+/-}$mice at P18-P21, PVINs were indistinguishable between genotype at P10 across all measures of intrinsic electrophysiological properties, single APs, and repetitive AP discharge (Fig. 2A, G-M, Tables 2, 3). We found no difference in maximal steady-state firing frequency between PVINs from Scnla ${ }^{+/-}$ ( $88 \pm 8 \mathrm{~Hz} ; n=19$ cells from 8 mice $)$ and wild-type $(84 \pm 8 \mathrm{~Hz}$; $n=17$ cells from 5 mice; $p=0.679$ vs $\left.\operatorname{Scn} 1 a^{+/-}\right)$. However, 
A P10 WT

P10 Scn1a $a^{+-}$

D $\quad$ P10

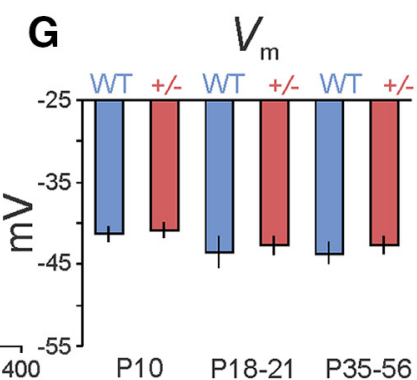

B P20 WT

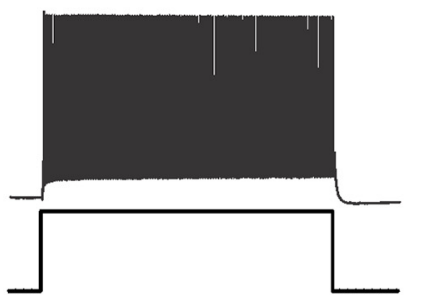

c P55 WT
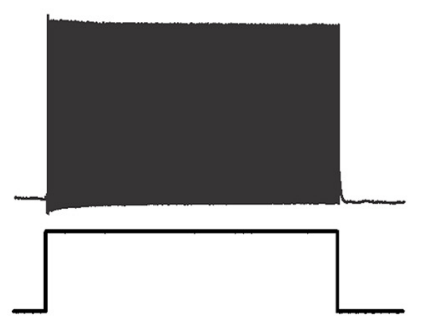

J Maximal firing

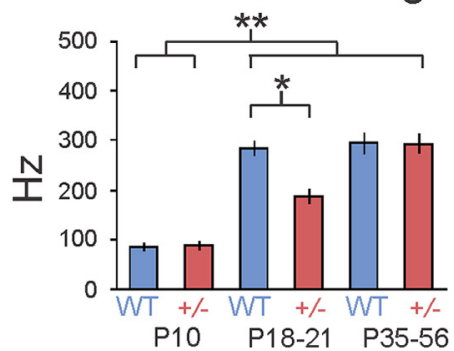

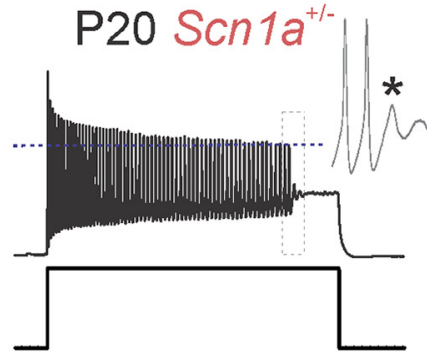

E
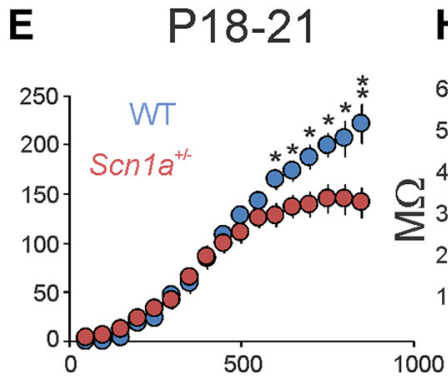

H Input resistance

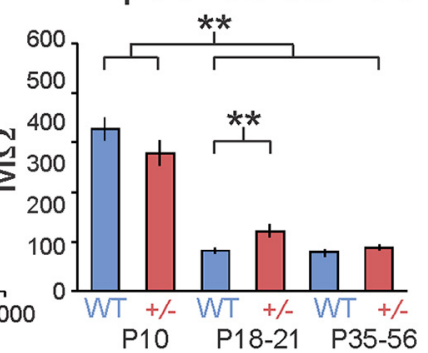

$\mathbf{F}$
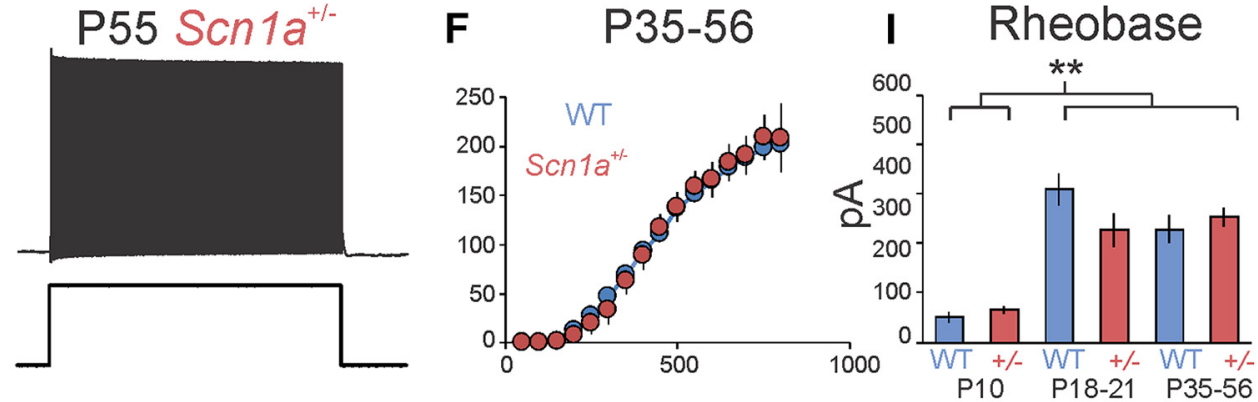

Rheobase

L AP threshold

\section{M}

Adaptation
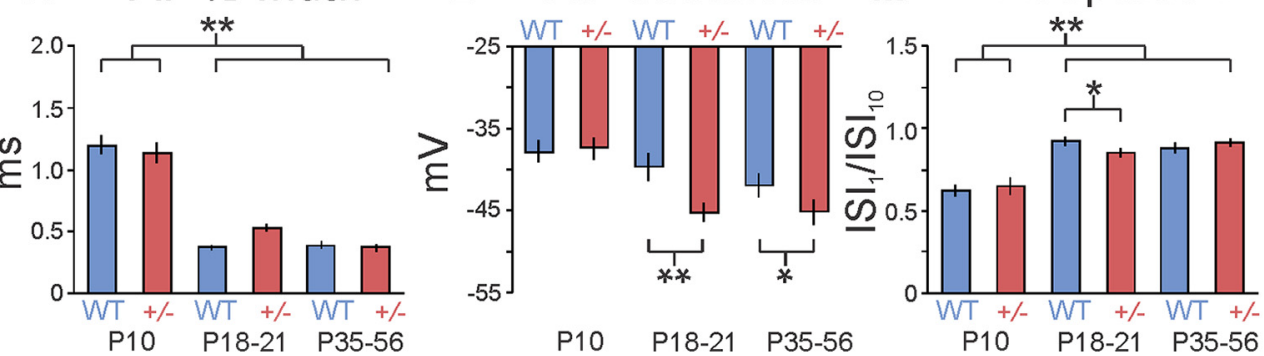

Figure 2. PV interneurons in $\mathrm{Scn} 1 a^{+/-}$mice exhibit profound yet transient abnormalities of intrinsic excitability. Shown are representative examples of a PVIN from a set of age-matched wild-type PV-Cre.tdT and Scn1a.PV-Cre.tdT mice at P10 (A), P20 (B), and P55 (C). A-C, at P10, wild-type and Scn1a ${ }^{+/-}$PVINs discharge the same number of APs (wild-type, 30; Scn1a ${ }^{+/-}, 29$ ) in response to a $250 \mathrm{pA}$ current injection (two times rheobase current injection). $\boldsymbol{B}$, Representative PVINs from an Scn1 $a^{+/-}$mouse at P20 (right) exhibits impaired excitability with decreased maximal firing frequency, prominent spike height accommodation, AP failures, and rundown of AHP amplitude during sustained firing compared with wild-type (right). Shown is the response to a $750 \mathrm{pA}$ current injection for both cells (wild-type, 115 spikes at $191.7 \mathrm{~Hz}$ steady-state firing frequency; $\mathrm{Scn} 1 a^{+/-}, 66$ spikes at $126.9 \mathrm{~Hz}$ in the epoch before failure). Note that all events with a 40 $\mathrm{mV}$ or greater amplitude from threshold that also cross $-10 \mathrm{mV}$ (indicated by the dotted line) are counted as spikes. Inset in $\boldsymbol{B}$ shows the boxed region at expanded resolution to highlight spike failures. $C$, Representative PVIN from an Scn $1 a^{+/-}$mouse at P55 shows normalization of high-frequency firing with a similar number of APs in response to a 750 pA current injection compared with wild-type (wild-type, 181 spikes at $301.7 \mathrm{~Hz}$ steady-state firing frequency; $S \mathrm{Cn} 1 a^{+/-}, 177$ spikes at $295.0 \mathrm{~Hz}$ ). D-F, Input- output (I-0) curves for PVINs in wild-type (blue) and Scn1a ${ }^{+/}-$mice (red) at P10 (D), P18-P21 (E), and P35-P56 (F). Note the progressive failure of AP generation with increasing current injection at P18-P21, with recovery of excitability at P35-P56. Asterisks indicate statistical significance across genotype within a given age group. ${ }^{*} p<0.05 ;{ }^{* *} p<0.01$. $\mathbf{G}-\mathbf{M}$, Summary data for resting membrane potential $(\boldsymbol{G})$, input resistance $(\boldsymbol{H})$, rheobase current injection $(\boldsymbol{I})$, maximal steady-state firing frequency during a $600 \mathrm{~ms}$ depolarizing pulse $(\boldsymbol{J})$, AP half-width $(\boldsymbol{K})$, AP voltage threshold $(\boldsymbol{L})$, and SFA $(\boldsymbol{M})$. Note that maximal firing frequency in $\boldsymbol{M}$ increases from P10 to P18, is higher for wild-type than $\mathrm{Scn} 1 a^{+/-}$at P18 -P21, then are again identical between genotype at P35-P56. The $n$ for each group (cells, mice) is as follows: P10 WT, 17 cells from 5 mice; P10 Scn1a ${ }^{+/-}, 19$ cells from 8 mice; P18 -P21 WT, 26 cells from 7 mice; P18-P21 Scn1a ${ }^{+/-}, 23$ cells from 9 mice; P35-P56 WT, 21 cells from 7 mice; P35-P56 Scn1a ${ }^{+/-}, 29$ cells from 11 mice. ${ }^{*} p<0.05 ;{ }^{* *} p<0.01$; for $S \mathrm{cn} 1 \mathrm{a}^{+/-}$versus wild-type within an age group or between age groups via Wald test. See Materials and Methods for details of the populationaveraged approach used to account for effects of genotype and age as well as multiple measurements (cells) taken from each animal.

PVINs in both wild-type and Scn1a ${ }^{+/-}$mice at P10 were statistically different from PVINs of both genotype at P18-P21 and P35-P56 in a range of measures of intrinsic excitability, repetitive firing, and the properties of individual APs, consistent with the known developmental trajectory of PVIN excitability (Fig. 2, Tables 2, 3; Goldberg et al., 2011).

Because PVINs at P10 do not exhibit the electrophysiological properties characteristic of mature PVINs (Goldberg et al., 2011), 


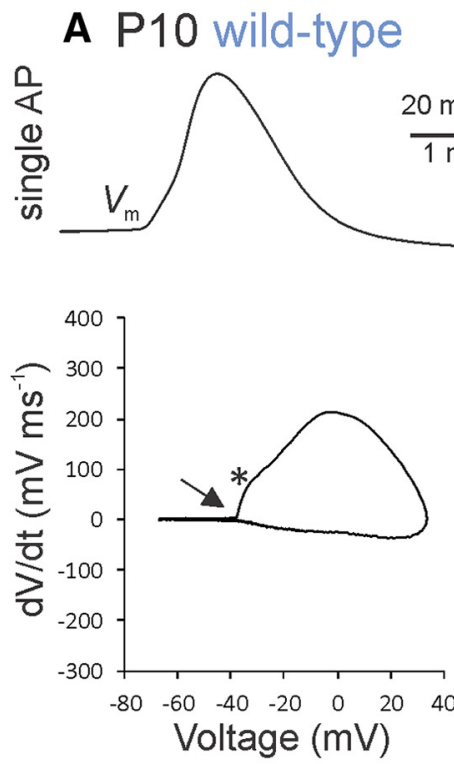

B P20 wild-type

C P44 wild-type

D P10 Scn1a ${ }^{+/-}$
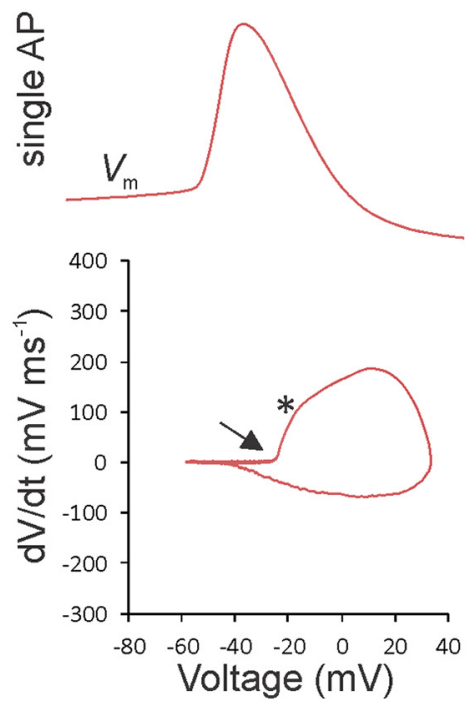
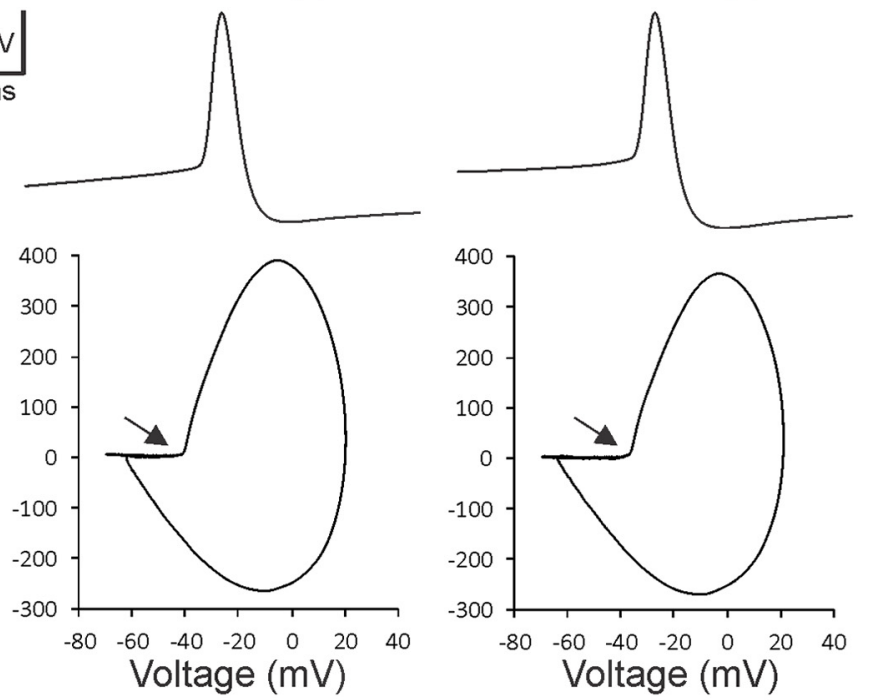

E P20 Scn1a
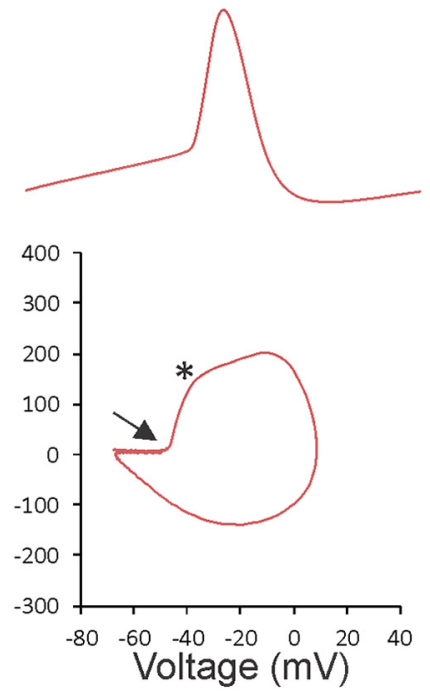

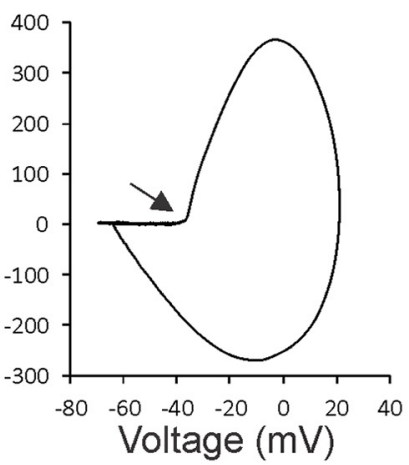

F P48 Scn1a
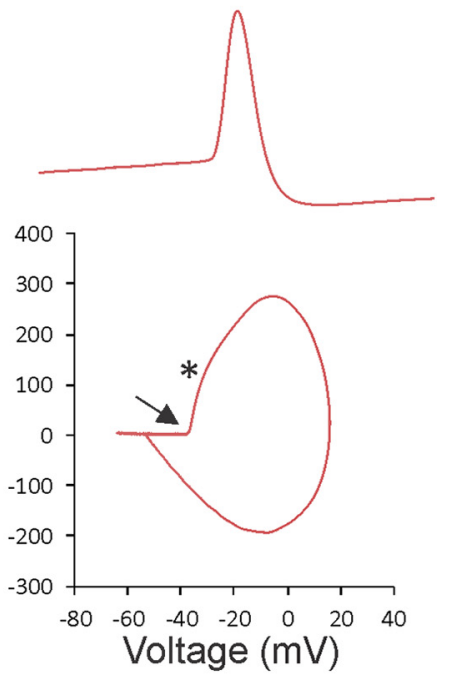

Figure 3. Phase plot analysis suggests altered localization of the AP initiation site in PVINs from $\mathrm{Scn} 1 a^{+/}$- mice with retained distal spike initiation. Shown are representative individual APs and corresponding phase plots from PVINs from wild-type $(\boldsymbol{A}-\boldsymbol{C})$ and $S \mathrm{cn} 1 a^{+/-}$mice $(\boldsymbol{D}-\boldsymbol{F})$ at each of the three time windows analyzed, including P10 $(\boldsymbol{A}, \boldsymbol{D}), \mathrm{P} 18-\mathrm{P} 21(\boldsymbol{B}, \boldsymbol{E})$, and P35-P56 $(\boldsymbol{C}, \boldsymbol{F})$. Phase plots were constructed from the first derivative (dV/dt; $y$-axis) versus membrane potential ( $\mathrm{mV} ; x$-axis) of an AP produced in response to an at-/near-threshold current injection. AP threshold is indicated with an arrow $\left(\rightarrow\right.$ ); a second inflection point ("bump"), if present, is indicated by an asterisk $\left(^{*}\right)$, reflecting remote initiation of the AP at a distal site followed by temporally separated somatic invasion. Note that the slope of the phase plot changes markedly between P10 and P18-P21 for wild-type PVINs, with an increase in the maximal slope and disappearance of inflection point in the rising phase.

Table 2. Electrophysiological properties of neocortical PVINs in wild-type versus $\operatorname{Sen} 1 a^{+/-}$mutant mice

\begin{tabular}{|c|c|c|c|c|c|c|c|c|c|c|}
\hline \multirow[b]{3}{*}{ Age group } & \multirow[b]{3}{*}{ Genotype } & \multirow{2}{*}{\multicolumn{2}{|c|}{$n$}} & \multirow[b]{3}{*}{ Age (d) } & \multirow{2}{*}{\multicolumn{3}{|c|}{ Intrinsic properties }} & \multicolumn{3}{|c|}{ Repetitive action potential discharge } \\
\hline & & & & & & & & \multicolumn{2}{|c|}{ Firing frequency $(\mathrm{Hz})$} & \multirow[b]{2}{*}{$\begin{array}{l}\text { Spike frequency } \\
\text { adaptation }|S|_{1} /|S|_{1}\end{array}$} \\
\hline & & Mice & Cells & & $V_{\mathrm{m}}(\mathrm{mV})$ & $R_{\mathrm{m}}(\mathrm{M} \Omega)$ & $\begin{array}{l}\text { Rheobase } \\
(\mathrm{pA})\end{array}$ & $\begin{array}{l}\text { Steady } \\
\text { state }\end{array}$ & Instant & \\
\hline \multirow[t]{2}{*}{ P10 } & WT & 5 & 17 & $10.0 \pm 0.0$ & $-66.3 \pm 1.0$ & $327 \pm 24$ & $50.4 \pm 10.6$ & $84 \pm 8$ & $160 \pm 12$ & $0.62 \pm 0.04$ \\
\hline & $\operatorname{Scn} 1 a^{+1-}$ & 8 & 19 & $10.0 \pm 0.0$ & $-65.8 \pm 1.0$ & $279 \pm 24$ & $64.9 \pm 8.3$ & $88 \pm 8$ & $154 \pm 12$ & $0.65 \pm 0.04$ \\
\hline P11-12 & WT & 3 & 7 & $11.7 \pm 0.2$ & $-66.1 \pm 3.1$ & $241 \pm 79$ & $85.3 \pm 25.8$ & $94 \pm 10$ & $183 \pm 18$ & $0.55 \pm 0.14$ \\
\hline P18-21 & $\operatorname{Sen} 1 a^{+1-}$ & 9 & 23 & $20.1 \pm 0.2$ & $-67.7 \pm 1.2$ & $121 \pm 12^{* *}$ & $226 \pm 34$ & $187 \pm 15^{*}$ & $256 \pm 20^{*}$ & $0.85 \pm 0.03^{*}$ \\
\hline \multirow[t]{2}{*}{ P35-56 } & WT & 7 & 21 & $45.1 \pm 1.2$ & $-68.6 \pm 1.4$ & $78 \pm 7$ & $228 \pm 27$ & $294 \pm 22$ & $349 \pm 17$ & $0.88 \pm 0.03$ \\
\hline & $\operatorname{Sen} 1 a^{+1-}$ & 11 & 29 & $46.3 \pm 1.4$ & $-67.6 \pm 1.0$ & $88 \pm 6$ & $252 \pm 20$ & $293 \pm 19$ & $368 \pm 22$ & $0.91 \pm 0.03$ \\
\hline
\end{tabular}

${ }^{*} p<0.05,{ }^{* *} p<0.01$ for $\mathrm{Scn} 1 a^{+1-}$ versus wild-type within a given age group via Wald test. 
Table 3. Properties of individual action potentials in PVINs in wild-type versus $\operatorname{Scn} 1 a^{+/-}$mice

\begin{tabular}{|c|c|c|c|c|c|c|c|c|c|c|c|}
\hline \multirow[b]{2}{*}{ Age group } & \multirow[b]{2}{*}{ Genotype } & \multicolumn{2}{|l|}{$n$} & \multirow{2}{*}{$\begin{array}{l}\text { Height } \\
(\mathrm{mV})\end{array}$} & \multirow{2}{*}{$\begin{array}{l}1 / 2 \text {-width } \\
\text { (ms) }\end{array}$} & \multirow[b]{2}{*}{$\mathrm{AHP}(\mathrm{mV})$} & \multicolumn{2}{|c|}{ AP threshold (mV) } & \multirow{2}{*}{$\begin{array}{l}\text { Max dV/ } \\
\mathrm{dt}(\mathrm{mV} / \mathrm{ms})\end{array}$} & \multirow{2}{*}{$\begin{array}{l}\text { Inflection } \\
\text { rate }\left(\mathrm{ms}^{-1}\right)\end{array}$} & \multirow{2}{*}{$\begin{array}{l}\text { Stationary } \\
\text { inflection } \\
\text { (yes/no) }\end{array}$} \\
\hline & & Mice & Cells & & & & Method 1 & Method 2 & & & \\
\hline \multirow[t]{2}{*}{ P10 } & WT & 5 & 17 & $65.2 \pm 2.5$ & $1.20 \pm 0.08$ & $16.0 \pm 1.1$ & $-37.8 \pm 1.3$ & $-40.7 \pm 1.5$ & $198 \pm 19$ & $19.2 \pm 2.1$ & 9/10 (90\%) \\
\hline & $\operatorname{Sen} 1 a^{+1-}$ & 8 & 19 & $63.0 \pm 2.4$ & $1.14 \pm 0.08$ & $17.6 \pm 1.0$ & $-37.4 \pm 1.3$ & $-41.2 \pm 1.4$ & $207 \pm 18$ & $19.9 \pm 2.0$ & $9 / 11(82 \%)$ \\
\hline \multirow[t]{2}{*}{ P18 -P21 } & WT & 7 & 26 & $54.3 \pm 1.8$ & $0.37 \pm 0.02$ & $20.1 \pm 0.8$ & $-39.7 \pm 1.7$ & $-41.9 \pm 1.5$ & $305 \pm 17$ & $16.7 \pm 2.7$ & $2 / 29(7 \%)$ \\
\hline & $\operatorname{Sen} 1 a^{+1-}$ & 9 & 23 & $59.6 \pm 2.2$ & $0.53 \pm 0.03 \dagger$ & $18.8 \pm 0.8$ & $-45.2 \pm 1.1^{*}$ & $-48.0 \pm 1.4^{* *}$ & $232 \pm 13$ & $12.6 \pm 0.8$ & $15 / 22(68 \%) \neq$ \\
\hline \multirow[t]{2}{*}{ P35-P56 } & WT & 7 & 21 & $59.0 \pm 2.8$ & $0.37 \pm 0.03$ & $23.4 \pm 3.1$ & $-41.9 \pm 1.4$ & $-42.8 \pm 1.3$ & $328 \pm 27$ & $13.3 \pm 1.0$ & $2 / 21(9 \%)$ \\
\hline & $\operatorname{Scn} 1 a^{+1-}$ & 11 & 29 & $60.5 \pm 2.4$ & $0.39 \pm 0.03$ & $24.5 \pm 3.0$ & $-45.1 \pm 1.5^{*}$ & $-45.1 \pm 1.5^{*}$ & $314 \pm 29$ & $16.9 \pm 1.7$ & $14 / 29(48 \%) \S$ \\
\hline
\end{tabular}

${ }^{*} p<0.05,{ }^{* *} p<0.01,+p=0.071$ for $\operatorname{Scn} 1 a^{+1-}$ versus wild-type within a given age group via Wald test.

$\neq p<0.05, \S p<0.01$ via $\chi^{2}$ test.

we independently confirmed that cells recorded at P10 were indeed interneurons via post hoc immunohistochemistry and visualization with confocal microscopy. We successfully recovered nine of 10 putative PVINs recorded from wild-type mice and determined eight of nine to be aspiny multipolar cells lacking an apical dendrite; none was pyramidal, although one was indeterminant due to low-quality cell fill. We recovered eight of $18 \mathrm{pu}-$ tative PVINs recorded from Scn $1 a^{+/-}$mice and confirmed six of eight to be aspiny multipolar cells lacking an apical dendrite; none was clearly pyramidal and two were indeterminant. PV immunopositivity in filled PVINs at P10 was weak or absent, likely due to low-level PV expression at P10 and/or dialysis of PV during whole-cell recording.

Although PVINs at P10 are identical between genotypes, the abnormalities in PVINs seen in $S c n 1 a^{+/-}$mice at P18-P21 become rapidly apparent by P11. Analysis of the P11-P12 data revealed lower maximal steady-state firing frequency (Table 2), with AP failure during repetitive firing in response to progressively larger amplitude current injections. Passive membrane properties, including resting membrane potential, input resistance, and rheobase current, were not different at this time point.

We then performed targeted recordings from PVINs in acute brain slices prepared from P35-P56 Scn1a ${ }^{+/-}$mice and agematched wild-type littermate controls and found that PVINs from $S \mathrm{cnla} \mathrm{a}^{+/-}$mice had recovered fast spiking; in fact, PVINs from $S \mathrm{cn} 1 \mathrm{a}^{+/-}$mice were capable of discharging sustained trains of APs at $>250 \mathrm{~Hz}$ for hundreds of milliseconds with minimal SFA and spike height accommodation (Fig. 2C,F,M, Table 3). Maximal steady-state firing frequency for PVINs from Scn $1 a^{+/-}$mice at P35P56 was $293 \pm 19 \mathrm{~Hz}$ ( $n=29$ cells from 11 mice) vs $294 \pm 22 \mathrm{~Hz}$ for wild-type ( $n=21$ cells from 7 mice; $p=0.92$ ) (Figs. $2 C-M, 3)$. At P35-P56, PVINs from Scn1a ${ }^{+/-}$mice had generally recovered normal excitability, being near-identical, on average, across a broad range of indices of intrinsic excitability, properties of single APs, and measures of repetitive AP generation, including resting membrane potential, input resistance, SFA, maximal firing frequency, AP threshold, and AP height (Tables 2, 3).

\section{Retained distal initiation of APs in mature $\mathrm{PV}^{+}$interneurons in mature $\operatorname{Scn} 1 a^{+/-}$mice}

The recovery of fast spiking in PVINs from $S c n 1 a^{+/-}$mice by P35 suggests the possibility of a compensatory plasticity mechanism, perhaps involving upregulation of $\mathrm{Na}^{+}$channels. To address the mechanism whereby neocortical PVINs recover fast spiking in Scnla ${ }^{+/-}$mice by P35, we performed more detailed analysis of individual APs to investigate potential genotypespecific differences in spike generation. Phase plot analysis (voltage vs $\mathrm{d} V / \mathrm{dt}$ ) allows for a more clear separation of the axonal and somatodendritic AP as recorded at the soma and we used this analysis to indirectly assess the distance of the spike generating zone from the soma in PVINs from wild-type vs $S c n 1 a^{+/-}$mice. At P18-P21, nearly all cells showed a single inflection point in the rising phase of the AP (Fig. 3B, Table 3), consistent with close temporal overlap between the axonal and somatodendritic spike, as would be expected based on the known proximal location of the spike generation zone in these cells ( $\mathrm{Hu}$ and Jonas, 2014). However, in PVINs from Scn $1 a^{+/-}$mice, we frequently observed a clear second inflection point, suggesting spatiotemporal separation between the axonal and somatodendritic spike (Fig. 3E). At P10, nearly all PVINs from wild-type and $S c n 1 a^{+/-}$mice exhibited two inflection points (Fig. $3 A, D$ ), suggesting that, at early time points before upregulation of Nav1.1, the site of spike generation in PVINs may be located more distally. At P35-P56, many PVINs from Scn $1 a^{+/-}$mice were still noted to possess two inflection points in the phase plot (Fig. $3 F$ ). To quantify these observations, we then calculated the second $\left(\mathrm{d}^{2} V / \mathrm{dt}^{2}\right)$ and third $\left(\mathrm{d}^{3} \mathrm{~V} / \mathrm{dt}^{3}\right)$ derivative of the AP from PVINs at the three developmental time windows for both genotypes (Fig. 4, Table 3); the second derivative (Fig. 4A3,B3) more clearly illustrates separation of two inflection point, corresponding to a value of $\mathrm{d}^{3} \mathrm{~V} / \mathrm{dt}^{3}$ that is equal to or less than zero (i.e., a stationary inflection (Kress et al., 2008); Fig. 4A4,B4). A stationary inflection was observed in the AP of most PVINs at P10 (9 of 10 wild-type and 9 of 12 Scn $1 a^{+/-}$cells analyzed; $p=0.53$ via Pearson's $\chi^{2}$ test; $\chi^{2}$ statistic, 0.39$)$. In contrast, at P18-P21, a stationary inflection was observed in 2 of 27 (7.4\%) of wild-type PVINs and 12/18 (66.7\%) of Scn1a ${ }^{+/-}$cells $\left(p=0.000026\right.$ via $\chi^{2}$ test; $\chi^{2}$ statistic, 17.7 ; Fig. $\left.4 C\right)$.

\section{No difference in the electrophysiological properties of pyramidal cells between $S c n 1 a^{+/-}$and wild-type across development}

Any compensatory mechanism that drives normalization of PVIN excitability in Scn1a $a^{+/-}$mice by P35 could be specific to PVINs or could represent a more global compensatory mechanism that occurs across cell types. To further assess the specificity of any effect on interneurons versus excitatory cells, we performed recordings from pyramidal neurons in layer $2 / 3$ primary somatosensory cortex at P18-P21 and P35-P56 and found no differences in the intrinsic electrophysiological properties, properties of single APs, or features or repetitive AP discharge between pyramidal cells from wild-type versus $\operatorname{Scn} 1 a^{+/-}$mice at either time point (Fig. 5, Tables 4, 5). At P35-P56, there was no difference in AP threshold, AP half-width, or maximal steady-state firing frequency between genotypes, suggesting that, if there is upregulation of $\mathrm{Na}^{+}$channel $\alpha$ subunits in pyramidal cells, this does not have any apparent functional effect on cellular neurophysiology, at least so far as can be assessed via whole-cell recording in the brain slice preparation. 
Structural plasticity of the AIS of $\mathrm{PV}^{+}$ interneurons in Scn1a ${ }^{+/-}$mice

The structure of the AIS as well as the location of ion channels expressed at the AIS is known to be regulated by neuronal activity (Grubb and Burrone, 2010; Kuba et al., 2010; Evans et al., 2015), with increased activity leading to AIS shortening. To attempt to provide anatomical evidence in support of structural differences in the AIS of PVINs between genotype, we performed immunohistochemistry for PV and the AIS marker ankyrin-G (Jenkins and Bennett, 2001; Hedstrom et al., 2008) and quantified the length of ankyrin-G immunoreactivity at the AIS of PVINs from Scn $1 a^{+/-}$vs wild-type mice at P18-P21 and P35-P56. We found that the AIS was longer in PVINs from Scn $1 a^{+/-}$mice than wild-type at P18P21 and that this difference persisted at P35-P56 (Fig. 6).

\section{Discussion}

Here, we show that PVINs in neocortex of a mouse model of Dravet syndrome $\left(\mathrm{Scn}_{1 a^{+/-}}\right.$mice) display near-normal electrophysiological properties compared with those recorded from age-matched wild-type littermate controls at later developmental time points (P35-P56). PVINs exhibit profoundly abnormal AP generation at earlier developmental time points (P11-P21), as has been shown previously (Yu et al., 2006; Ogiwara et al., 2007; Hedrich et al., 2014; Tai et al., 2014; Tsai et al., 2015; De Stasi et al., 2016); however, such abnormalities are in fact transient. Although the mechanism of initial onset of epilepsy in Dravet syndrome may reflect the relative dependence of interneurons on Navl.1 relative to excitatory principal cells, our findings challenge the hypothesis that the basis of ongoing epilepsy in Dravet syndrome and chronic epilepsyassociated comorbid intellectual disability and autism spectrum disorder is dysfunctional AP generation or impaired highfrequency firing of PVINs.

The mechanism whereby PVINs in Scnla ${ }^{+/-}$mice recover functional spike generation by P35 requires further investigation, but likely involves upregulation of other voltage-gated $\mathrm{Na}^{+}$channels in PVINs. We found that PVINs in Scn1a $a^{+/-}$ at P11-P21 show impaired AP generation as measured by lower steady-state and instantaneous firing frequency and increased SFA during sustained trains of APs with prominent spike height accommodation and AP failures, consistent with decreased $\mathrm{Na}^{+}$current; analysis of individual APs revealed increased AP 1/2-width (broader spikes), prolonged rise time, and decreased maximal

\section{A P20 wild-type B P20 Scn1a $a^{+-}$}
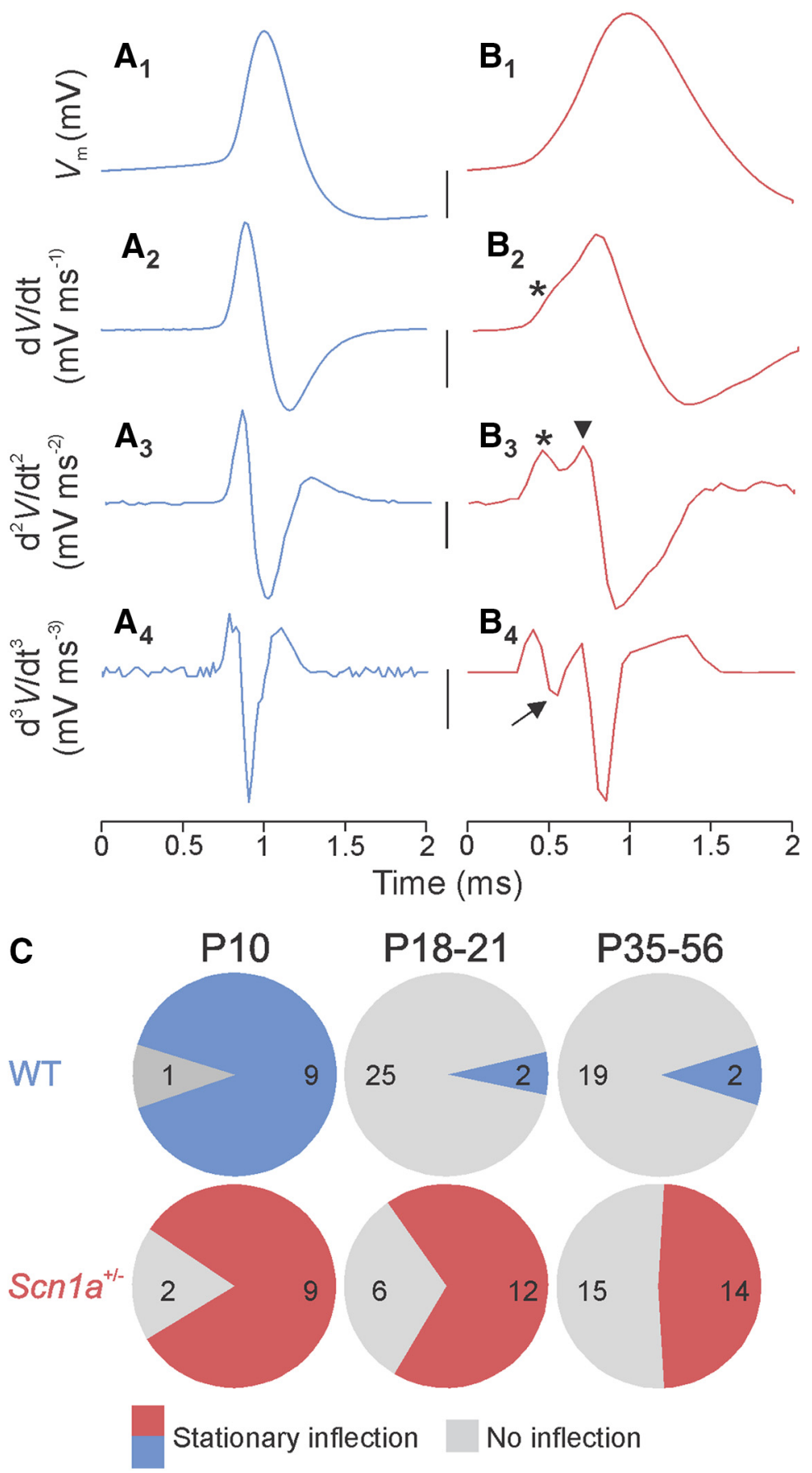

Figure 4. Analysis of somatic APs suggests a more distal initiation site in PVINs from $\mathrm{Ccn}_{1} a^{+/-}$mice compared with wild-type. Shown is a representative example of a PVIN spike from a wild-type $(A)$ and $S \mathrm{Cn} 1 a^{+/-}$mouse at the P18-P21 time window (P20 for each cell), illustrating the voltage waveform of the $\mathrm{AP}(\boldsymbol{A} \mathbf{1}$ and $\boldsymbol{B} \mathbf{1}$; in $\mathrm{mV})$, and first ( $\boldsymbol{A} \mathbf{2}$ and $\boldsymbol{B} \mathbf{2} ; \mathrm{dV} / \mathrm{dt}$, in $\mathrm{mV} / \mathrm{ms})$, second ( $\boldsymbol{A} \mathbf{3}$ and $B 3 ; \mathrm{d}^{2} V / \mathrm{dt}^{2}$, in $\left.\mathrm{mV} / \mathrm{ms}^{2}\right)$, and third derivative $\left(\boldsymbol{A} 4\right.$ and $B \mathbf{B} ; \mathrm{d}^{3} \mathrm{~V} / \mathrm{dt}^{3}$, in $\left.\mathrm{mV} / \mathrm{ms}^{3}\right)$ of the AP. Asterisk (*) indicates the first (nonstationary) inflection point in the $\mathrm{dV} / \mathrm{dt}$ trace, with the first $\left(^{*}\right)$ and second (arrowhead) inflection points indicated in the $\mathrm{d}^{2} V / \mathrm{dt}^{2}$ trace in $B 3$. The $\mathrm{d}^{3} \mathrm{~V} / \mathrm{dt}^{3}$ is a quantitative measure of a second inflection point (i.e., stationary inflection in the $\mathrm{d}^{2} \mathrm{~V} / \mathrm{dt}^{2}$ trace), as determined by the presence or absence of point where the $\mathrm{d}^{3} \mathrm{~V} / \mathrm{dt}^{3}$ trace is less than or equal to zero (indicated by an arrow in B4), which was present in only 2 of 27 PVINs (6.9\%) recorded from $n=7$ wild-type mice at P18 -P21 but was observed in $68.2 \%$ of cells $(15 / 22)$ from $n=9 \mathrm{Scn} 1 a^{+l-}$ mice $\left(p=0.00009\right.$ via $\chi^{2}$ test). Scale bars are as follows: $A 1, B 1,20 \mathrm{mV} ; A 2,200$ $\mathrm{mV} \mathrm{ms}{ }^{-1} ; B 2,100 \mathrm{mV} \mathrm{ms}^{-1} ; A 3,2 \times 10^{3} \mathrm{mV} \mathrm{ms}^{-3} ; B 3,4 \times 10^{2} \mathrm{mV} \mathrm{ms}^{-3} ; A 4,5 \times 10^{4} \mathrm{mV} \mathrm{ms}^{-3} ;$ and $B 4,5 \times 10^{3} \mathrm{mV}$ $\mathrm{ms}^{-3}$. C, Pie graphs highlighting the frequency with which a stationary inflection is observed in wild-type versus $\operatorname{Sen} 1 a^{+/-}$ PVINs across development. By P35-P56, 2 of 16 PVINs recorded from $n=6$ wild-type mice but 14 of 29 PVINs from $n=11$ $\operatorname{Scn} 1 a^{+/-}$mice retain a stationary inflection in the AP waveform ( $p=0.016$ comparing effect of genotype at P35-P56 via $\chi^{2}$ test). 
A P18 wild-type B P19 Scn1a $\quad$ C P41 willd-type D P45 Scn1a ${ }^{+-}$
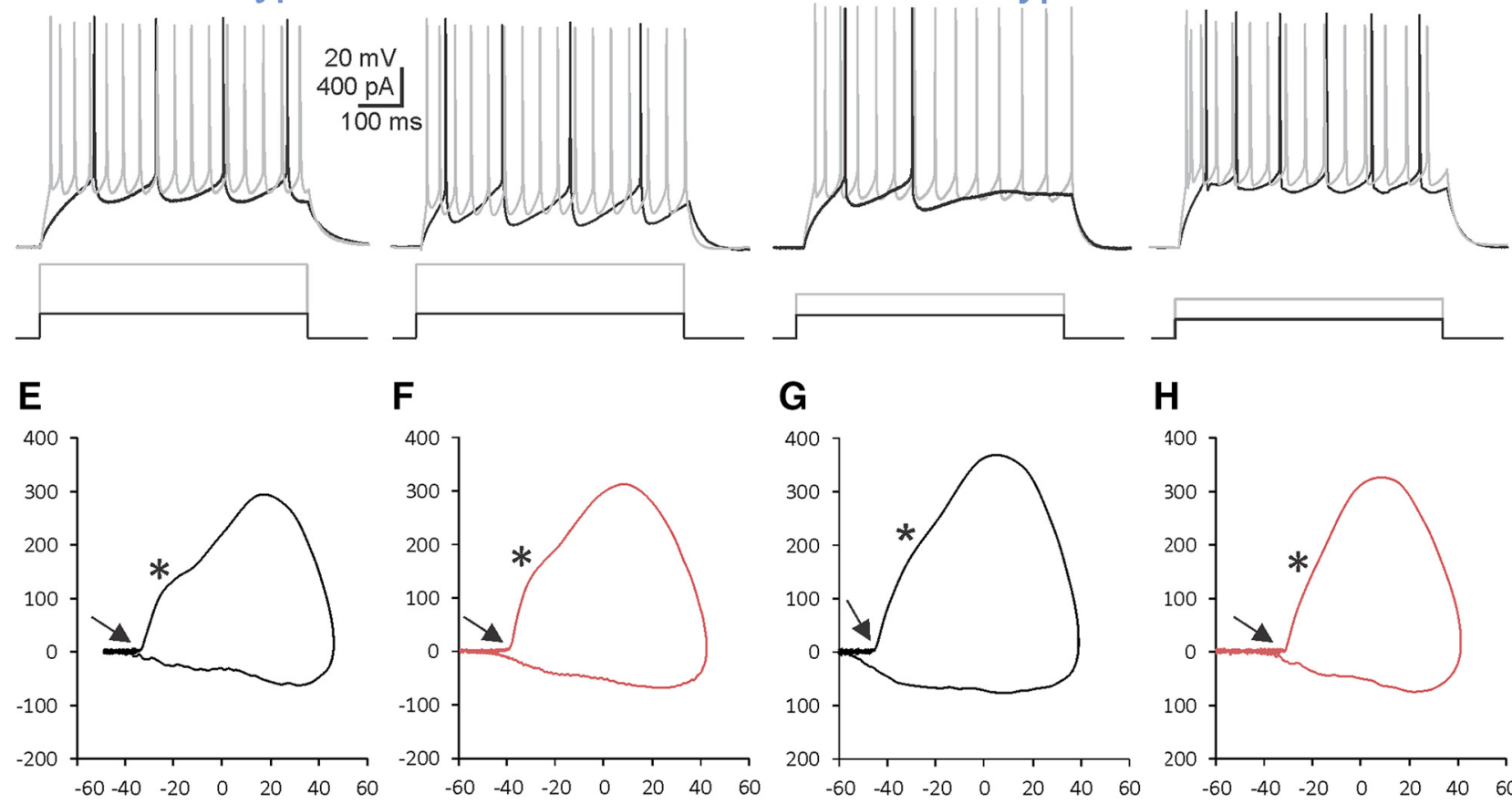

F

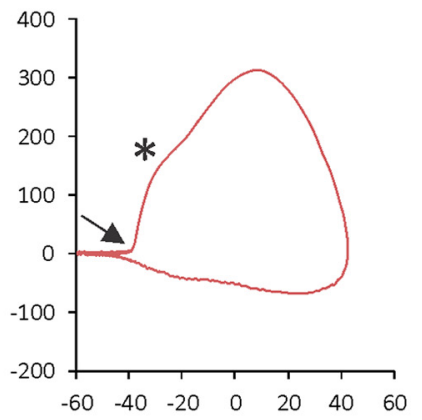

G

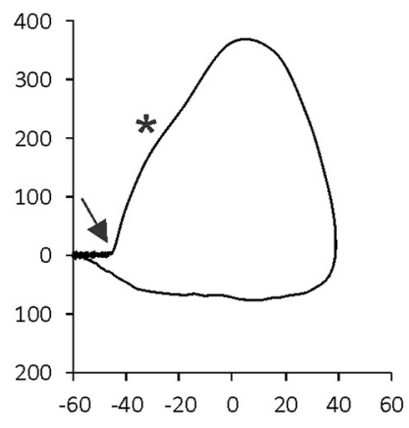

$\mathrm{J}_{1}$

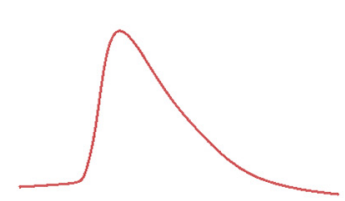

$\mathrm{K}_{1}$
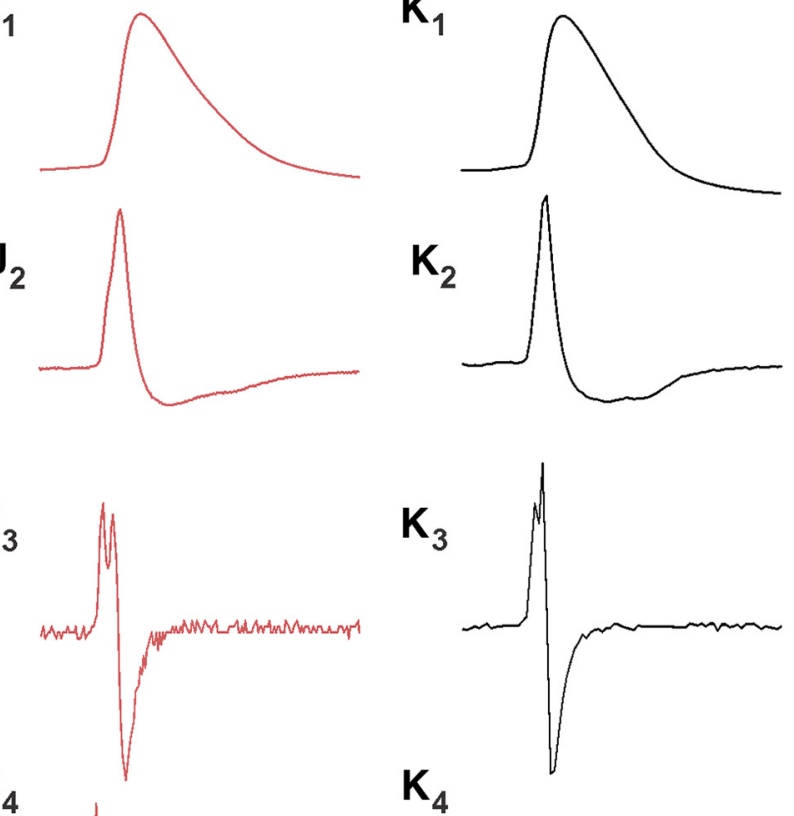

$\mathbf{J}_{4}$
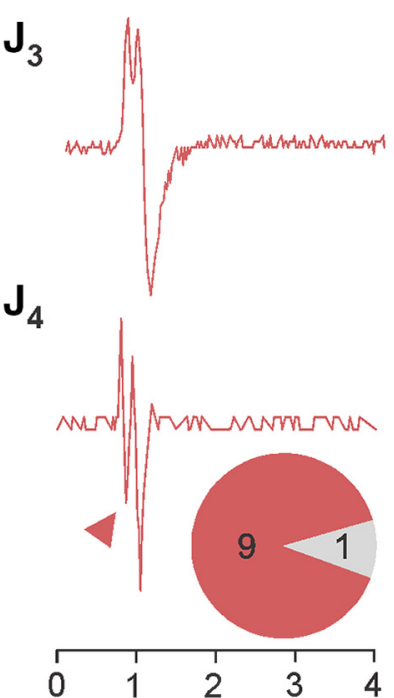

$\mathrm{L}_{2}$

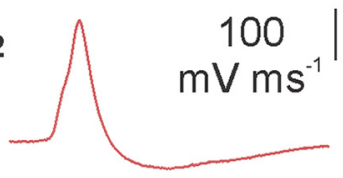

H

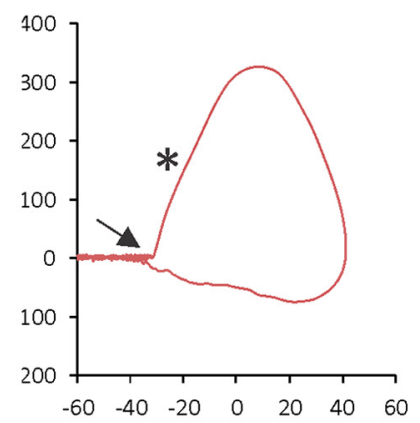

$\mathbf{L}_{1}$

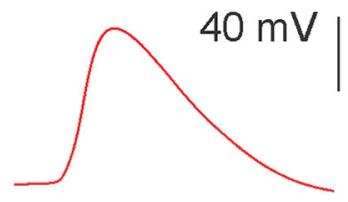

100 $\mathrm{mV} \mathrm{ms}^{-1}$

$\mathrm{L}_{3}$

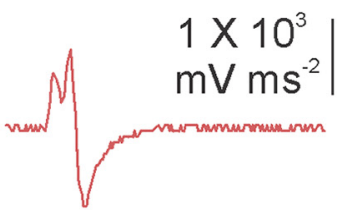

$\mathrm{L}_{4}$

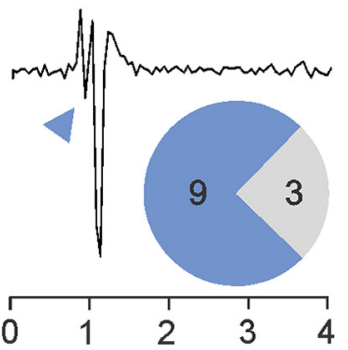

$2 \times 10^{4}$ $\mathrm{mV} \mathrm{ms}^{-3}$

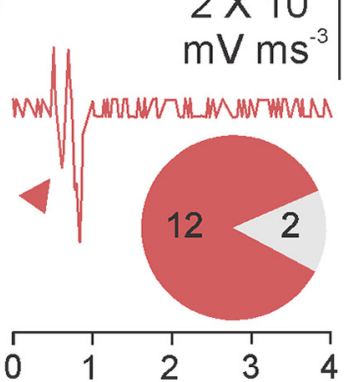

Figure 5. There were no apparent differences between individual pyramidal cell APs between $\operatorname{Scn} 1 a^{+/-}$mice and age-matched wild-type control. $\boldsymbol{A}-\boldsymbol{D}$, Representative examples of firing patterns for pyramidal cells from wild-type and Scn1a ${ }^{+/-}$mice. A, Response of a wild-type P18 pyramidal cell to rheobase (250 pA) current injection (black) and three-times rheobase (750 pA; gray). $\boldsymbol{B}$, Response of a Scn1a $a^{+/-}$P19 pyramidal cell to rheobase (250 pA) current injection (black) and three-times rheobase (750 pA; gray). C, Response of a wild-type P41 pyramidal cell to rheobase (250 pA) current injection (black) and two-times rheobase (500 pA; gray). D, Response of an Scn1a ${ }^{+1}$ P45 pyramidal cell to rheobase (200 pA) current injection (black) and two-times rheobase (400 pA; gray). For the cells shown in C (wild-type) and $\boldsymbol{D}\left(\operatorname{Scn} 1 a^{+/-}\right.$), the mutant cell happens to fire more APs at rheobase (wild-type, 2 spikes; $S \mathrm{cn} 1 a^{+/-}, 6$ spikes), whereas maximal steady-state firing frequency is slightly higher for this particular wild-type cell over the course of a $600 \mathrm{~ms}$ step depolarization (wild-type, $45 \mathrm{~Hz}$; $\mathrm{Scn}_{1 a^{+\prime}}{ }^{-}, 38.3 \mathrm{~Hz}$ ). (Figure legend continues.) 
Table 4. Electrophysiological properties of neocortical layer $2 / 3$ pyramidal cells in wild-type versus $\operatorname{Scn} 1 a^{+/-}$mutant mice

\begin{tabular}{|c|c|c|c|c|c|c|c|c|c|c|c|}
\hline \multirow[b]{3}{*}{ Age group } & \multirow[b]{3}{*}{ Genotype } & \multirow{2}{*}{\multicolumn{2}{|c|}{$n$}} & \multirow[b]{3}{*}{ Age (d) } & \multirow{2}{*}{\multicolumn{3}{|c|}{ Intrinsic properties }} & \multicolumn{4}{|c|}{ Repetitive action potential discharge } \\
\hline & & & & & & & & \multicolumn{2}{|c|}{ Firing frequency $(\mathrm{Hz})$} & \multicolumn{2}{|c|}{ Spike frequency adaptation } \\
\hline & & Mice & Cells & & $V_{\mathrm{m}}(\mathrm{mV})$ & $R_{\mathrm{m}}(\mathrm{M} \Omega)$ & $\begin{array}{l}\text { Rheobase } \\
(\mathrm{pA})\end{array}$ & Steady-state & Instantaneous & $|S|_{1} /|S|_{10}$ & $|S|_{1} /|S|_{n}$ \\
\hline \multirow[t]{2}{*}{ P18-P21 } & WT & 4 & 10 & $18.2 \pm 0.2$ & $-71.5 \pm 2.2$ & $117 \pm 11$ & $138 \pm 21$ & $38.3 \pm 2.1$ & $115 \pm 12$ & $0.78 \pm 0.02$ & $0.53 \pm 0.03$ \\
\hline & $\operatorname{Scn} 1 a^{+/-}$ & 4 & 10 & $18.5 \pm 0.2$ & $-70.3 \pm 2.7$ & $126 \pm 21$ & $121 \pm 14$ & $39.3 \pm 3.5$ & $132 \pm 30$ & $0.82 \pm 0.02$ & $0.53 \pm 0.06$ \\
\hline P35-P56 & WT & 4 & 12 & $44.4 \pm 0.7$ & $-74.9 \pm 1.9$ & $85 \pm 14$ & $269 \pm 43$ & $44.9 \pm 2.8$ & $190 \pm 21$ & $0.35 \pm 0.04$ & $0.30 \pm 0.03$ \\
\hline
\end{tabular}

Table 5. Properties of individual action potentials in pyramidal cells in wild-type versus $\operatorname{Sen} 1 a^{+/-}$mutant mice

\begin{tabular}{|c|c|c|c|c|c|c|c|c|c|c|c|c|}
\hline \multirow[b]{2}{*}{ Age group } & \multirow[b]{2}{*}{ Genotype } & \multicolumn{2}{|l|}{$n$} & \multirow[b]{2}{*}{ Age (d) } & \multirow[b]{2}{*}{ Height (mV) } & \multirow[b]{2}{*}{$1 / 2$-width (ms) } & \multirow[b]{2}{*}{$\mathrm{AHP}(\mathrm{mV})$} & \multicolumn{2}{|c|}{ AP threshold (mV) } & \multirow{2}{*}{$\begin{array}{l}\text { Max slope } \\
\text { (mV/ms) }\end{array}$} & \multirow{2}{*}{$\begin{array}{l}\text { Inflection } \\
\text { rate (mV/ms) }\end{array}$} & \multirow{2}{*}{$\begin{array}{l}\text { Stationary } \\
\text { inflection } \\
\text { (yes/no) }\end{array}$} \\
\hline & & Mice & Cells & & & & & Method 1 & Method 2 & & & \\
\hline P18-P21 & WT & 4 & 10 & $18.2 \pm 0.2$ & $74.0 \pm 0.6$ & $1.16 \pm 0.03$ & $17.6 \pm 0.7$ & $-38.2 \pm 2.1$ & $-38.4 \pm 2.1$ & $265 \pm 12$ & $16.6 \pm 2.3$ & $8 / 10(80 \%)$ \\
\hline \multirow[t]{2}{*}{ P35-P56 } & WT & 4 & 12 & $44.4 \pm 0.7$ & $71.5 \pm 1.8$ & $1.00 \pm 0.05$ & $11.6 \pm 2.6$ & $-38.4 \pm 1.5$ & $-38.5 \pm 1.5$ & $264 \pm 16$ & $13.1 \pm 0.9$ & 9/12(75\%) \\
\hline & $\operatorname{Scn} 1 a^{+1-}$ & 5 & 14 & $42.4 \pm 1.4$ & $76.0 \pm 2.4$ & $1.02 \pm 0.09$ & $13.9 \pm 0.6$ & $-39.4 \pm 2.1$ & $-39.4 \pm 2.2$ & $269 \pm 25$ & $16.2 \pm 3.5$ & $12 / 14(86 \%)$ \\
\hline
\end{tabular}

slope of the AP, all of which are parameters that depend on $\mathrm{Na}^{+}$ channel function. By P35, such differences were absent. Our results suggest the possibility that such normalization involves compensatory upregulation of non-Nav1.1 $\mathrm{Na}^{+}$channel $\alpha$ subunits (such as the other brain-expressed subunits Nav1.2, 1.3, and/or 1.6) or perhaps the upregulation of Nav1.1 itself. Prior work from others suggests that there might indeed be upregulation of non-Nav1.1 $\mathrm{Na}^{+}$ channel $\alpha$ subunits in Scn1a ${ }^{+/-}$mice, including an early report showing increased immunostaining for Nav1.3, but not 1.2 or 1.6, in $\mathrm{GAD}^{+}$cells in hippocampus of Scn1 $a^{+/-}$and, to a greater extent, in Scn1 $1 a^{-1-}$ mice, although this was not observed in neocortex (Yu et al., 2006). Liu et al. (2013) found increased excitability and $\mathrm{Na}^{+}$ current density in both bipolar-shaped GABA-expressing cells and pyramidal-shaped neurons derived from iPSCs from human patients with Dravet syndrome related to iPSC-derived neurons from healthy controls; these investigators did not find increased levels of any other $\mathrm{Na}^{+}$channel RNA transcripts, suggesting a possible posttranslational mechanism of increased $\mathrm{Na}^{+}$channel expression. Our data suggest that, if there is upregulation of $\mathrm{Na}^{+}$current in principal cells, then this has no obvious effect on pyramidal cell function at either P18-P21 or P35-P56, at least so far as was assessed in this study. Future work including detailed immunohistochemistry for various $\mathrm{Na}^{+}$channel $\alpha$ subunits and/or expression profiling will be required to confirm whether there is upregulation of non-Nav1.1 $\mathrm{Na}^{+}$channel $\alpha$ subunits in PVINs and principal cells. It should be noted that a normalization of PVIN function over time in Dravet syndrome does align with the known natural history of epilepsy in this condition because overall seizure frequency tends to decrease with time (Scheffer, 2012; Connolly, 2016). However, patients do continue to have treatment-resistant epilepsy and increased risk of SUDEP. Scnla $a^{+/-}$mice also continue to have chronic epilepsy at

\footnotetext{
$\leftarrow$

(Figure legend continued.) $\quad \boldsymbol{E}-\boldsymbol{H}$, phase plots $\left(V_{\mathrm{m}} \mathrm{vs} \mathrm{d} V / \mathrm{dt}\right.$ ) for the first AP at rheobase for the same cells shown in $\boldsymbol{A}-\boldsymbol{D}$. Indicated is the presence of two inflection points, with the "bump" in the rising phase highlighted with an asterisk $\left(^{*}\right)$ in each phase plot. $\boldsymbol{I}-\boldsymbol{L}$, The APs shown in $\boldsymbol{E}-\boldsymbol{H}$ $(\mathbf{I 1}, \boldsymbol{J 1}, \boldsymbol{K 1}, \mathbf{L 1})$, first derivative (dV/dt, in $\mathrm{mV} / \mathrm{ms} ; \mathbf{I 2}, \mathbf{J 2}, \boldsymbol{K 2}, \mathbf{L 2})$, second derivative $\left(\mathrm{d}^{2} V / \mathrm{dt}^{2}\right.$, in $\left.\mathrm{mV} / \mathrm{ms}^{2} ; \boldsymbol{I}, \boldsymbol{J} \mathbf{3}, \mathbf{K} \mathbf{3}, \mathbf{L} 3\right)$, and third derivative $\left(\mathrm{d}^{3} \mathrm{~V} / \mathrm{dt}^{3}\right.$, in $\left.\mathrm{mV} / \mathrm{ms}^{3} ; \mathbf{I}, \mathbf{J} 4, \boldsymbol{K} 4, \mathbf{L} 4\right)$. Note that in each second derivative $\mathrm{d}^{2} V / \mathrm{dt}^{2}$ trace, there are two well separated peaks after AP threshold and a stationary inflection (arrowhead) in each third derivative trace where $\mathrm{d}^{3} \mathrm{~V} / \mathrm{dt}^{3}$ is less than zero in the initial (axonal) component of the waveform, which is a quantitative indicator of a well separated axonal and somatic component of the AP waveform. Proportion of cells exhibiting a stationary inflection is shown in the pie charts (yes, blue/red; no, gray).
}

and beyond P56 with spontaneous seizures and SUDEP-like phenomena and actually have a lower threshold for temperatureinduced seizures at this age relative to earlier developmental time points (Oakley et al., 2009), although seizure frequency decreases markedly at/after P40 (Miller et al., 2014; Mistry et al., 2014).

It is a widely held view that conventional antiseizure medications with a predominant mechanism of action of $\mathrm{Na}^{+}$channel blockade, such as lamotrigine, are contraindicated in Dravet syndrome (Guerrini et al., 1998; Wirrell et al., 2017). A recent clinical report suggested that a subset of patients with Dravet syndrome might respond well to lamotrigine (Dalic et al., 2015). Interestingly, all patients in this recent report were 4 years of age or older (range, 4-21 years) when lamotrigine was introduced. Data suggest that, overall, $\operatorname{Scn} 1 a^{+/-}$mice respond similarly to antiseizure medications as human patients (Hawkins et al., 2017), including worsening of epilepsy with lamotrigine, although this was only tested in young mice $(\leq \mathrm{P} 30)$. A recent study showed that chronic treatment of $\mathrm{Scnla}{ }^{+/-}$mice with the $\mathrm{Na}^{+}$channel blocker GS967 actually decreased seizure frequency and improved survival (Anderson et al., 2017), although this compound may act at least in part via preferential blockade of persistent/slowly inactivating $\mathrm{Na}^{+}$current.

As noted above, our data at P18-P21 largely reproduce those reported previously (Ogiwara et al., 2007; Tai et al., 2014; Rubinstein et al., 2015b; Tsai et al., 2015; De Stasi et al., 2016). However, we also found that input resistance was higher and the voltage threshold for AP generation was lower (more negative/hyperpolarized) in PVINs from Scn $1 a^{+/-}$mice compared with wild-type littermate controls at P18-P21. Tai et al. (2014) previously reported an increase in rheobase with no change in the input resistance in PVINs in Scnla $a^{+/-}$mice, although there were multiple differences in the experimental conditions, including a different genetic background, broader age range included in the dataset (P14-P22), and differences in recording temperature (room temperature) (Table 1). De Stasi et al. (2016) reported slightly decreased input resistance and no change in the rheobase or in AP threshold, although this study was performed in younger mice (P16-P18) in a different Scn1 $a^{+/-}$mouse model maintained on a variable genetic background. We would argue that a lower apparent voltage threshold for AP generation might be consistent with a more distal spike initiation site (Kole and Stuart, 2008). All other things being equal, higher input resistance will lead to a 

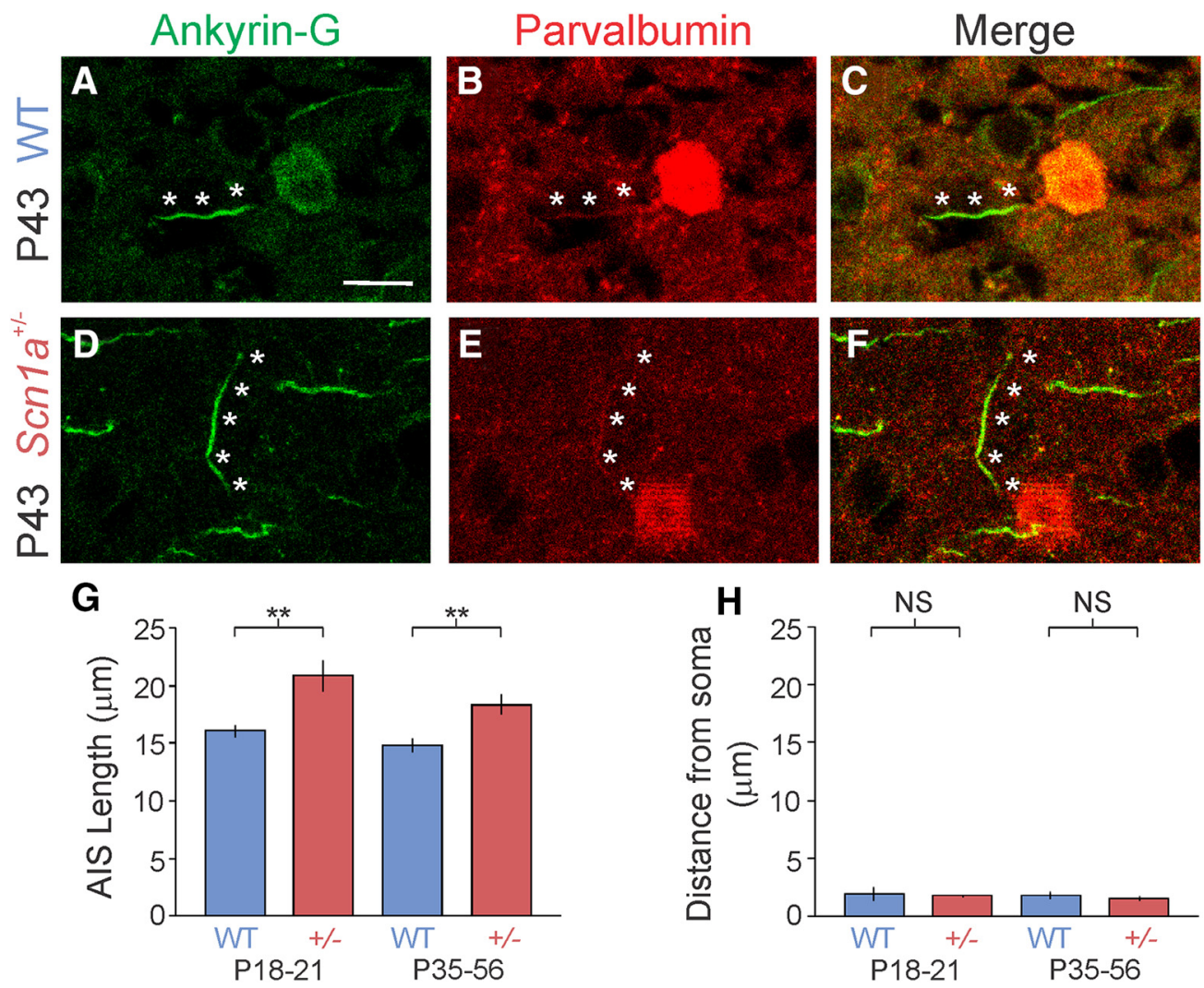

Figure 6. The $\mathrm{PV}^{+}$interneuron AIS is longer in $\mathrm{Scn} 1 a^{+/-}$mice compared with age-matched wild-type controls. $\boldsymbol{A}-\boldsymbol{C}$, An example AIS from a PVIN from a P43 wild-type mouse, showing ankyrin-G immunoreactivity $\left(\boldsymbol{A}\right.$; green), PV immunoreactivity ( $\boldsymbol{B}$; red), and overlay (C). D- $\boldsymbol{F}$, An AIS from a PVIN from an age-matched P43 Scn $1 a^{+/-}$mouse. PVIN AIS location is quantified as the

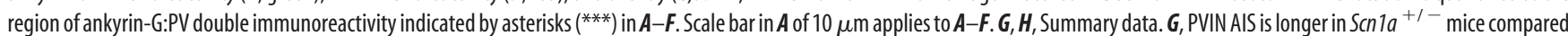
with wild-type at P18-P21 (wild-type $=16.02 \pm 0.52 \mu \mathrm{m}, n=55$ cells from 3 mice; $S \mathrm{cn} 1 a^{+/-}=20.86 \pm 0.57, n=96$ cells from 4 mice; $p<0.001$ via one-way ANOVA $\left(F_{(3,239)}=19.544\right.$ ) with correction for multiple comparisons using Bonferroni's test, a difference that persisted at P35-P56 (wild-type $=14.78 \pm 0.56 \mu \mathrm{m}, n=49$ cells from 3 mice; Scn 1a ${ }^{+l-}=18.34 \pm 0.91$, $n=42$ cells from 3 mice; $p=0.0061$ via one-way ANOVA with correction for multiple comparisons using Bonferroni's test). $\boldsymbol{H}$, Distance from the soma to the start of the ankyrin-G-immunoreactive segment of the axon was unchanged: wild-type at P18-P21, $1.89+/-0.15 \mu \mathrm{m} ; \mathrm{Scn}_{1} a^{+/}-\mathrm{P} 18-\mathrm{P} 21,1.71+/-0.21 \mu \mathrm{m}$; wild-type P35-P56, 1.73 +/ $-0.25 \mu \mathrm{m} ; \mathrm{Scn} 1 a^{+/}-\mathrm{P} 35-\mathrm{P} 56,1.50+/-$ $0.11 \mu \mathrm{m}$. There were no differences between groups via one-way ANOVA $\left(F_{(3,329)}=0.7764 ; p=0.5082\right.$ ). All measurements were performed blinded to genotype. ${ }^{* *} p<0.01$ (cf. $p<0.05$ ).

lower observed value for rheobase current injection, which in turn could be due to delayed or arrested development of PVIN excitability, with PVINs known to exhibit rapid postnatal maturation across multiple properties including, prominently, of input resistance (Goldberg et al., 2011). Alternatively, this higher input resistance could itself be a compensatory or homeostatic mechanism to attempt to recover PVIN excitability.

It is well known that there are strong genetic background effects on behavioral phenotypes in rodent models, including on epilepsy (Crawley et al., 1997; Schauwecker, 2002, 2011, 2012; Yang and Frankel, 2004), and the phenotype of $S \mathrm{cnla} a^{+1-}$ is known to be strongly dependent upon mouse genetic background, the basis of which is under investigation (Miller et al., 2014; Mistry et al., 2014; Rubinstein et al., 2015b). Rubinstein et al. (2015b) showed that somatic $\mathrm{Na}^{+}$currents recorded from bipolar-shaped putative GABAergic interneurons dissociated from hippocampus are reduced in $\mathrm{Scnla}^{+1-}$ mice relative to wild-type controls on a C57BL/6J but not on a pure $129 \mathrm{~S} 6$ background at P14-P16, but not at P21-P24. Excitability of putative stratum oriens interneurons recorded in acute brain slices prepared from Scn1a ${ }^{+/-}$mice on a C57BL/6J background at P21P24 remained impaired. The precise identity of the neurons targeted for recording in this study is not clear, but these cells are unlikely to have been PVINs based on both anatomical and physiological criteria. Mistry et al. (2014) performed recordings from dissociated neurons in culture prepared from the same Scn1a ${ }^{+1-}$ mouse strain used in the present study and showed decreased $I_{\mathrm{Na}}$ density in bipolar putative GABAergic interneurons dissociated from hippocampus of $S \mathrm{cnla} \mathrm{a}^{+/-}$mice relative to wild-type controls at P21-P24. Therefore, the existing data suggest that there is decreased $I_{\mathrm{Na}}$ density in putative interneurons dissociated from hippocampus of the same Dravet syndrome mouse line used in the present study. Because of the above considerations, we chose to use a previously validated, well characterized, and publicly available Dravet syndrome line that also closely recapitulates the core features of Dravet syndrome as observed in human patients and with which a strict and consistent genetic background can be confidently maintained (Miller et al., 2014; Mistry et al., 2014).

Potential reasons why normalization of PVIN excitability at/ after P35 has not been noted previously are as follows. Scn1a $a^{+1-}$ mice exhibit markedly increased mortality starting at P16-P18 (Yu et al., 2006; Mistry et al., 2014), so it may be difficult to accumulate a sufficient cohort of experimental animals at later ages. We used a PV-Cre transgenic mouse (Taniguchi et al., 2011) that facilitated efficient identification and targeted recording of PVINs in acute brain slices, as well as post hoc immunohistochemistry and imaging of cellular anatomy as necessary. We also used a rigorous breeding strategy that allowed for the generation of wild-type and Scn1 1a $a^{+1-}$ PV-Cre.tdT mice on a strict 50:50 C57:129S6 background. We focused specifically on superficial layers of primary somatosensory ("barrel") cortex in mice because this brain region is heavily studied and well characterized; 
additional work will be required to determine whether our findings generalize to PVINs in deep layers and to other neocortical brain regions and the hippocampus.

A recent study found no difference between the mean firing frequency of PVINs in Scn $1 a^{+/-}$versus wild-type mice in vivo using juxtacellular recordings in ketamineanesthetized animals (De Stasi et al., 2016). That study represents the only work that includes electrophysiological recordings from individual defined neuronal subtypes (PVINs and putative pyramidal cells) in Scnla ${ }^{+/-}$mice in vivo. However, ketamine is known to suppress the activity of PVINs in vivo (Quirk et al., 2009) and the mean firing rate of PVINs under ketamine anesthesia in the De Stasi et al. (2016) study was $<15 \mathrm{~Hz}$ for all cells, whereas PVINs are known to fire at much higher frequency $(>100 \mathrm{~Hz})$ under specific conditions in vivo (Letzkus et al., 2011; Lapray et al., 2012; Varga et al., 2012). Therefore, it is likely that, under these recording conditions, the firing rate of PVINs is too low to see a difference between genotypes.

Our findings are a striking example of an emerging theme in the study of mechanisms of neurodevelopmental disorders in which cellular or circuit phenotypes identified at one particular developmental stage or time point prove transient (Krol and Feng, 2018; Del Pino et al., 2018). This raises the question: if PVINs are indeed normal or nearly normal at P35 and beyond in Scn1a ${ }^{+/-}$ mice, then what is the cellular/circuit mechanism underlying continued cognitive and behavioral abnormalities, temperaturesensitive seizures, and epilepsy in these mice? One possibility is that other, non-PV interneurons such as SST-INs (Tai et al., 2014; Rubinstein et al., 2015a) or perhaps interneurons in other brain areas (such as hippocampus) do not undergo compensation and remain dysfunctional. Alternatively, it could be that transient dysfunction of PVINs during a critical temporal window during the first $2-4$ postnatal weeks in mouse has permanent consequences for circuit formation that is sufficient to underlie the chronic epilepsy and neurocognitive impairment seen in $\mathrm{Scnla}^{+/-}$mice. It is well known that inhibition, specifically maturation of PVINs, is known to regulate critical periods for experience-dependent plasticity in neocortex such as ocular dominance plasticity (Hensch, 2005; Griffen and Maffei, 2014). Development of PVIN intrinsic excitability itself is known to be activity dependent (Berghuis et al., 2004), with sensory deprivation impairing development of inhibition provided by PVINs (Kuhlman et al., 2013). Plasticity of inhibition from PVINs is a mechanism balancing synaptic excitation and inhibition in cerebral cortical circuits (Xue et al., 2014). Therefore, transient hypofunction of PVINs during early development could conceivably lead to permanent hyperexcitability that underlies longlasting circuit dysfunction in $\mathrm{Scnla}^{+/-}$mice.

It could be the case that, whereas PVINs recover normal AP initiation, these cells remain subtly abnormal. Paired soma:axon recordings from PVINs indicated that APs are initiated proxi- mally $10-20 \mu \mathrm{m}$ from the soma (Hu and Jonas, 2014); this is in contrast to layer 5 neocortical pyramidal cells, in which the site of AP initiation is estimated to be $35-50 \mu \mathrm{m}$ from the soma (Palmer and Stuart, 2006; Kole et al., 2007; Shu et al., 2007). $\mathrm{Na}^{+}$current density in PVIN axons is "supercritical" in that it is far in excess of what is required to guarantee reliable AP propagation; this high density of axonal $\mathrm{Na}^{+}$channels contributes to the fast-spiking phenotype and is required for AP propagation speed ( $\mathrm{Hu}$ and Jonas, 2014). Our analysis of single APs suggests that there may be a migration of the spike generating zone to more proximal axon in PVINs during development under normal conditions and that this does not occur in PVINs from Scnla ${ }^{+/-}$mice. In PVINs, Nav1.1 is known to localize to the proximal and Nav1.6 to the distal AIS (Li et al., 2014). We speculate that loss of Nav1.1 at the proximal AIS with compensatory upregulation of non-Nav1.1 $\mathrm{Na}^{+}$channels at the distal AIS recovers high-frequency firing, but perhaps fails to fully reconstitute normal axonal function (Fig. 7). Our data obtained using whole-cell somatic currentclamp recordings is suggestive yet indirect; we also provide anatomical evidence that the AIS is in fact longer in PVINs from $\operatorname{Scn} 1 a^{+/-}$mice. Detailed immunohistochemical analysis of $\mathrm{Na}^{+}$ channel $\alpha$ subunits at the AIS of PVINs of Scnla $a^{+1-}$ mice and age-matched wild-type controls at various ages, direct axonal recordings from interneuron axons (Hu and Jonas, 2014; Li et al., 2014). Computational modeling could further elucidate the precise details of the anatomical localization and molecular composition of AIS $\mathrm{Na}^{+}$channels in PV-INs in wild-type versus Scn $1 a^{+/-}$mice across development and the functional implica- 
tions of these developmentally regulated changes. Specific PVIN axonal dysfunction could have profound effects on cerebral cortical circuit function including in the timing of feedforward and feedback inhibition and the generation of gamma-frequency network oscillations (Bartos et al., 2007; Cardin et al., 2009; Sohal et al., 2009), impairments of which could be related to the pathogenesis of epilepsy and epilepsy-associated cognitive abnormalities in Dravet syndrome.

Finally, our results demonstrating that impaired AP generation by PVINs is transient in Scn1a ${ }^{+/-}$mice suggests the existence of a potentially limited window for therapeutic intervention via a strategy involving upregulation of Na1.1. Such efforts, with an Nav1.1-specific peptide toxin or small-molecule channel opener (Osteen et al., 2016; Frederiksen et al., 2017) or via upregulation of Nav1.1 using gene therapy (Bechi et al., 2015; Hsiao et al., 2016) are ongoing. Our results suggest that, if instituted early on in the course of the disease and in a cell-typespecific fashion, such efforts might indeed prove effective; however, if instituted after PVINs have undergone compensatory reorganization of axonal $\mathrm{Na}^{+}$channels, then such interventions might have no effect or might even worsen the symptoms of Dravet syndrome.

\section{References}

Alshammari MA, Alshammari TK, Laezza F (2016) Improved methods for fluorescence microscopy detection of macromolecules at the axon initial segment. Front Cell Neurosci 10:5. CrossRef Medline

Anderson LL, Hawkins NA, Thompson CH, Kearney JA, George AL Jr (2017) Unexpected efficacy of a novel sodium channel modulator in Dravet syndrome. Sci Rep 7:1682. CrossRef Medline

Bartos M, Vida I, Jonas P (2007) Synaptic mechanisms of synchronized gamma oscillations in inhibitory interneuron networks. Nat Rev Neurosci 8:45-56. CrossRef Medline

Bechi G, Rusconi R, Cestèle S, Striano P, Franceschetti S, Mantegazza M (2015) Rescuable folding defective NaV1.1 (SCN1A) mutants in epilepsy: Properties, occurrence, and novel rescuing strategy with peptides targeted to the endoplasmic reticulum. Neurobiol Dis 75:100-114. CrossRef Medline

Berghuis P, Dobszay MB, Sousa KM, Schulte G, Mager PP, Härtig W, Görcs TJ, Zilberter Y, Ernfors P, Harkany T (2004) Brain-derived neurotrophic factor controls functional differentiation and microcircuit formation of selectively isolated fast-spiking GABAergic interneurons. Eur J Neurosci 20:1290-1306. CrossRef Medline

Cardin JA, Carlén M, Meletis K, Knoblich U, Zhang F, Deisseroth K, Tsai LH, Moore CI (2009) Driving fast-spiking cells induces gamma rhythm and controls sensory responses. Nature 459:663-667. CrossRef Medline

Catterall WA (2000) From ionic currents to molecular mechanisms: the structure and function of voltage-gated sodium channels. Neuron 26:1325. CrossRef Medline

Catterall WA (2012) Voltage-gated sodium channels at 60: structure, function and pathophysiology. J Physiol 590:2577-2589. CrossRef Medline

Chattopadhyaya B, Di Cristo G, Higashiyama H, Knott GW, Kuhlman SJ, Welker E, Huang ZJ (2004) Experience and activity-dependent maturation of perisomatic GABAergic innervation in primary visual cortex during a postnatal critical period. J Neurosci 24:9598-9611. CrossRef Medline

Cheah CS, Yu FH, Westenbroek RE, Kalume FK, Oakley JC, Potter GB, Rubenstein JL, Catterall WA (2012) Specific deletion of NaV1.1 sodium channels in inhibitory interneurons causes seizures and premature death in a mouse model of Dravet syndrome. Proc Natl Acad Sci U S A 109: 14646-14651. CrossRef Medline

Claes L, Del-Favero J, Ceulemans B, Lagae L, Van Broeckhoven C, De Jonghe P (2001) De novo mutations in the sodium-channel gene SCN1A cause severe myoclonic epilepsy of infancy. Am J Hum Genet 68:1327-1332. CrossRef Medline

Connolly MB (2016) Dravet syndrome: diagnosis and long-term course. Can J Neurol Sci 43:S3-S8. CrossRef Medline

Crawley JN, Belknap JK, Collins A, Crabbe JC, Frankel W, Henderson N, Hitzemann RJ, Maxson SC, Miner LL, Silva AJ, Wehner JM, Wynshaw-
Boris A, Paylor R (1997) Behavioral phenotypes of inbred mouse strains: implications and recommendations for molecular studies. Psychopharmacology (Berl) 132:107-124. CrossRef Medline

Dalic L, Mullen SA, Roulet Perez E, Scheffer I (2015) Lamotrigine can be beneficial in patients with Dravet syndrome. Dev Med Child Neurol 57: 200-202. CrossRef Medline

Defelipe J, et al. (2013) New insights into the classification and nomenclature of cortical GABAergic interneurons. Nat Rev Neurosci 14:202-216. CrossRef Medline

Del Pino I, Rico B, Marín O (2018) Neural circuit dysfunction in mouse models of neurodevelopmental disorders. Curr Opin Neurobiol 48:174182. CrossRef Medline

de Lecea L, del Río JA, Soriano E (1995) Developmental expression of parvalbumin mRNA in the cerebral cortex and hippocampus of the rat. Brain Res Mol Brain Res 32:1-13. CrossRef Medline

De Stasi AM, Farisello P, Marcon I, Cavallari S, Forli A, Vecchia D, Losi G, Mantegazza M, Panzeri S, Carmignoto G, Bacci A, Fellin T (2016) Unaltered network activity and interneuronal firing during spontaneous cortical dynamics in vivo in a mouse model of severe myoclonic epilepsy of infancy. Cereb Cortex 26:1778-1794. CrossRef Medline

Dravet C (2011) The core Dravet syndrome phenotype. Epilepsia 52:3-9. CrossRef Medline

Dutta S, Sengupta P (2016) Men and mice: relating their ages. Life Sci 152: 244-248. CrossRef Medline

Evans MD, Dumitrescu AS, Kruijssen DLH, Taylor SE, Grubb MS (2015) Rapid modulation of axon initial segment length influences repetitive spike firing. Cell Rep 13:1233-1245. CrossRef Medline

Frederiksen K, Lu D, Yang J, Jensen HS, Bastlund JF, Larsen PH, Liu H, Crestey F, Dekermendjian K, Badolo L, Laursen M, Hougaard C, Yang C, Svenstrup N, Grunnet M (2017) A small molecule activator of nav 1.1 channels increases fast-spiking interneuron excitability and GABAergic transmission in vitro and has anti-convulsive effects in vivo. Eur J Neurosci 46:1887-1896. CrossRef Medline

Goldberg EM, Jeong HY, Kruglikov I, Tremblay R, Lazarenko RM, Rudy B (2011) Rapid developmental maturation of neocortical FS cell intrinsic excitability. Cereb Cortex 21:666-682. CrossRef Medline

Griffen TC, Maffei A (2014) GABAergic synapses: their plasticity and role in sensory cortex. Front Cell Neurosci 8:91. CrossRef Medline

Grubb MS, Burrone J (2010) Activity-dependent relocation of the axon initial segment fine-tunes neuronal excitability. Nature 465:1070-1074. CrossRef Medline

Guerrini R, Dravet C, Genton P, Belmonte A, Kaminska A, Dulac O (1998) Lamotrigine and seizure aggravation in severe myoclonic epilepsy. Epilepsia 39:508-512. CrossRef Medline

Han S, Tai C, Westenbroek RE, Yu FH, Cheah CS, Potter GB, Rubenstein JL, Scheuer T, de la Iglesia HO, Catterall WA (2012) Autistic-like behaviour in Scnla $+/$ - mice and rescue by enhanced GABA-mediated neurotransmission. Nature 489:385-390. CrossRef Medline

Hawkins NA, Anderson LL, Gertler TS, Laux L, George AL Jr, Kearney JA (2017) Screening of conventional anticonvulsants in a genetic mouse model of epilepsy. Ann Clin Transl Neurol 4:326-339. CrossRef Medline

Hedrich UB, Liautard C, Kirschenbaum D, Pofahl M, Lavigne J, Liu Y, Theiss S, Slotta J, Escayg A, Dihné M, Beck H, Mantegazza M, Lerche H (2014) Impaired action potential initiation in GABAergic interneurons causes hyperexcitable networks in an epileptic mouse model carrying a human NaV1.1 mutation. J Neurosci 34:14874-14889. CrossRef Medline

Hedstrom KL, Ogawa Y, Rasband MN (2008) AnkyrinG is required for maintenance of the axon initial segment and neuronal polarity. J Cell Biol 183:635-640. CrossRef Medline

Hensch TK (2005) Critical period plasticity in local cortical circuits. Nat Rev Neurosci 6:877-888. CrossRef Medline

Higurashi N, Uchida T, Lossin C, Misumi Y, Okada Y, Akamatsu W, Imaizumi Y, Zhang B, Nabeshima K, Mori MX, Katsurabayashi S, Shirasaka Y, Okano H, Hirose S (2013) A human Dravet syndrome model from patient induced pluripotent stem cells. Mol Brain 6:19. CrossRef Medline

Hsiao J, Yuan TY, Tsai MS, Lu CY, Lin YC, Lee ML, Lin SW, Chang FC, Liu Pimentel H, Olive C, Coito C, Shen G, Young M, Thorne T, Lawrence M, Magistri M, Faghihi MA, Khorkova O, Wahlestedt C (2016) Upregulation of haploinsufficient gene expression in the brain by targeting a long non-coding RNA improves seizure phenotype in a model of Dravet syndrome. EBioMedicine 9:257-277. CrossRef Medline

$\mathrm{Hu} \mathrm{H}$, Jonas P (2014) A supercritical density of $\mathrm{Na}+$ channels ensures fast 
signaling in GABAergic interneuron axons. Nat Neurosci 17:686-693. CrossRef Medline

Jenkins SM, Bennett V (2001) Ankyrin-G coordinates assembly of the spectrin-based membrane skeleton, voltage-gated sodium channels, and L1 CAMs at Purkinje neuron initial segments. J Cell Biol 155:739-746. CrossRef Medline

Jiao J, Yang Y, Shi Y, Chen J, Gao R, Fan Y, Yao H, Liao W, Sun XF, Gao S (2013) Modeling Dravet syndrome using induced pluripotent stem cells (iPSCs) and directly converted neurons. Hum Mol Genet 22:4241-4252. CrossRef Medline

Kalume F, Westenbroek RE, Cheah CS, Yu FH, Oakley JC, Scheuer T, Catterall WA (2013) Sudden unexpected death in a mouse model of Dravet syndrome. J Clin Invest 123:1798-1808. CrossRef Medline

Kole MH, Stuart GJ (2008) Is action potential threshold lowest in the axon? Nat Neurosci 11:1253-1255. CrossRef Medline

Kole MH, Letzkus JJ, Stuart GJ (2007) Axon initial segment Kv1 channels control axonal action potential waveform and synaptic efficacy. Neuron 55:633-647. CrossRef Medline

Kress GJ, Dowling MJ, Meeks JP, Mennerick S (2008) High threshold, proximal initiation, and slow conduction velocity of action potentials in dentate granule neuron mossy fibers. J Neurophysiol 100:281-291. CrossRef Medline

Krol A, Feng G (2018) Windows of opportunity: timing in neurodevelopmental disorders. Curr Opin Neurobiol 48:59-63. CrossRef Medline

Kuba H, Oichi Y, Ohmori H (2010) Presynaptic activity regulates $\mathrm{Na}+$ channel distribution at the axon initial segment. Nature 465:1075-1078. CrossRef Medline

Kuhlman SJ, Olivas ND, Tring E, Ikrar T, Xu X, Trachtenberg JT (2013) A disinhibitory microcircuit initiates critical-period plasticity in the visual cortex. Nature 501:543-546. CrossRef Medline

Lapray D, Lasztoczi B, Lagler M, Viney TJ, Katona L, Valenti O, Hartwich K, Borhegyi Z, Somogyi P, Klausberger T (2012) Behavior-dependent specialization of identified hippocampal interneurons. Nat Neurosci 15: 1265-1271. CrossRef Medline

Letzkus JJ, Wolff SBE, Meyer EM, Tovote P, Courtin J, Herry C, Lüthi A (2011) A disinhibitory microcircuit for associative fear learning in the auditory cortex. Nature 480:331-335. CrossRef Medline

Li T, Tian C, Scalmani P, Frassoni C, Mantegazza M, Wang Y, Yang M, Wu S, Shu Y (2014) Action potential initiation in neocortical inhibitory interneurons. PLoS Biol 12:e1001944. CrossRef Medline

Liu Y, Lopez-Santiago LF, Yuan Y, Jones JM, Zhang H, O’Malley HA, Patino GA, O'Brien JE, Rusconi R, Gupta A, Thompson RC, Natowicz MR, Meisler MH, Isom LL, Parent JM (2013) Dravet syndrome patientderived neurons suggest a novel epilepsy mechanism. Ann Neurol 74: 128-139. CrossRef Medline

Lorincz A, Nusser Z (2008) Cell-type-dependent molecular composition of the axon initial segment. J Neurosci 28:14329-14340. CrossRef Medline

Madisen L, Zwingman TA, Sunkin SM, Oh SW, Zariwala HA, Gu H, Ng LL, Palmiter RD, Hawrylycz MJ, Jones AR, Lein ES, Zeng H (2010) A robust and high-throughput Cre reporting and characterization system for the whole mouse brain. Nat Neurosci 13:133-140. CrossRef Medline

Meeks JP, Mennerick S (2007) Action potential initiation and propagation in CA3 pyramidal axons. J Neurophysiol 97:3460-3472. CrossRef Medline

Miller AR, Hawkins NA, McCollom CE, Kearney JA (2014) Mapping genetic modifiers of survival in a mouse model of Dravet syndrome. Genes Brain Behav 13:163-172. CrossRef Medline

Mistry AM, Thompson CH, Miller AR, Vanoye CG, George AL Jr, Kearney JA (2014) Strain- and age-dependent hippocampal neuron sodium currents correlate with epilepsy severity in Dravet syndrome mice. Neurobiol Dis 65:1-11. CrossRef Medline

Naundorf B, Wolf F, Volgushev M (2006) Unique features of action potential initiation in cortical neurons. Nature 440:1060-1063. CrossRef Medline

Nicholas CR, Chen J, Tang Y, Southwell DG, Chalmers N, Vogt D, Arnold CM, Chen YJ, Stanley EG, Elefanty AG, Sasai Y, Alvarez-Buylla A, Rubenstein JL, Kriegstein AR (2013) Functional maturation of hPSC-derived forebrain interneurons requires an extended timeline and mimics human neural development. Cell Stem Cell 12:573-586. CrossRef Medline

Oakley JC, Kalume F, Yu FH, Scheuer T, Catterall WA (2009) Temperatureand age-dependent seizures in a mouse model of severe myoclonic epi- lepsy in infancy. Proc Natl Acad Sci U S A 106:3994-3999. CrossRef Medline

Ogiwara I, Miyamoto H, Morita N, Atapour N, Mazaki E, Inoue I, Takeuchi T, Itohara S, Yanagawa Y, Obata K, Furuichi T, Hensch TK, Yamakawa K (2007) Nav1.1 localizes to axons of parvalbumin-positive inhibitory interneurons: a circuit basis for epileptic seizures in mice carrying an Scn1a gene mutation. J Neurosci 27:5903-5914. CrossRef Medline

Ogiwara I, Nakayama T, Yamagata T, Ohtani H, Mazaki E, Tsuchiya S, Inoue Y, Yamakawa K (2012) A homozygous mutation of voltage-gated sodium channel $\$ \beta \$(\mathrm{I})$ gene SCN1B in a patient with Dravet syndrome. Epilepsia 53:e200-e203. CrossRef Medline

O'Malley HA, Isom LL (2015) Sodium channel $\beta$ subunits: emerging targets in channelopathies. Annu Rev Physiol 77:481-504. CrossRef Medline

Osteen JD, et al. (2016) Selective spider toxins reveal a role for the Nav1.1 channel in mechanical pain. Nature 534:494-499. CrossRef Medline

Palmer LM, Stuart GJ (2006) Site of action potential initiation in layer 5 pyramidal neurons. J Neurosci 26:1854-1863. CrossRef Medline

Pangratz-Fuehrer S, Hestrin S (2011) Synaptogenesis of electrical and GABAergic synapses of fast-spiking inhibitory neurons in the neocortex. J Neurosci 31:10767-10775. CrossRef Medline

Quirk MC, Sosulski DL, Feierstein CE, Uchida N, Mainen ZF (2009) A defined network of fast-spiking interneurons in orbitofrontal cortex: responses to behavioral contingencies and ketamine administration. Front Syst Neurosci 3:13. CrossRef Medline

Rubinstein M, Han S, Tai C, Westenbroek RE, Hunker A, Scheuer T, Catterall WA (2015a) Dissecting the phenotypes of Dravet syndrome by gene deletion. Brain 138:2219-2233. CrossRef Medline

Rubinstein M, Westenbroek RE, Yu FH, Jones CJ, Scheuer T, Catterall WA (2015b) Genetic background modulates impaired excitability of inhibitory neurons in a mouse model of Dravet syndrome. Neurobiol Dis 73: 106-117. CrossRef Medline

Schauwecker PE (2002) Complications associated with genetic background effects in models of experimental epilepsy. Prog Brain Res 135:139-148. CrossRef Medline

Schauwecker PE (2012) Strain differences in seizure-induced cell death following pilocarpine-induced status epilepticus. Neurobiol Dis 45:297304. CrossRef Medline

Schauwecker PE (2011) The relevance of individual genetic background and its role in animal models of epilepsy. Epilepsy Res 97:1-11. CrossRef Medline

Scheffer IE (2012) Diagnosis and long-term course of Dravet syndrome. Eur J Paediatr Neurol 16:S5-S8. CrossRef Medline

Semple BD, Blomgren K, Gimlin K, Ferriero DM, Noble-Haeusslein LJ (2013) Brain development in rodents and humans: Identifying benchmarks of maturation and vulnerability to injury across species. Prog Neurobiol 106-107:1-16. CrossRef Medline

Shu Y, Duque A, Yu Y, Haider B, McCormick DA (2007) Properties of action-potential initiation in neocortical pyramidal cells: evidence from whole cell axon recordings. J Neurophysiol 97:746-760. CrossRef Medline

Sohal VS, Zhang F, Yizhar O, Deisseroth K (2009) Parvalbumin neurons and gamma rhythms enhance cortical circuit performance. Nature 459: 698-702. CrossRef Medline

Sun AX, Yuan Q, Tan S, Xiao Y, Wang D, Khoo AT, Sani L, Tran HD, Kim P, Chiew YS, Lee KJ, Yen Y-C, Ng HH, Lim B, Je HS (2016a) Direct induction and functional maturation of forebrain GABAergic neurons from human pluripotent stem cells. Cell Rep 16:1942-1953. CrossRef Medline

Sun Y, Paşca SP, Portmann T, Goold C, Worringer KA, Guan W, Chan KC, Gai H, Vogt D, Chen YJ, Mao R, Chan K, Rubenstein JL, Madison DV, Hallmayer J, Froehlich-Santino WM, Bernstein JA, Dolmetsch RE (2016b) A deleterious Nav1.1 mutation selectively impairs telencephalic inhibitory neurons derived from Dravet syndrome patients. Elife 5:e13073. CrossRef Medline

Tai C, Abe Y, Westenbroek RE, Scheuer T, Catterall WA (2014) Impaired excitability of somatostatin- and parvalbumin-expressing cortical interneurons in a mouse model of Dravet syndrome. Proc Natl Acad Sci U S A 111:E3139-E148. CrossRef Medline

Taniguchi H, He M, Wu P, Kim S, Paik R, Sugino K, Kvitsiani D, Kvitsani D, Fu Y, Lu J, Lin Y, Miyoshi G, Shima Y, Fishell G, Nelson SB, Huang ZJ (2011) A resource of Cre driver lines for genetic targeting of GABAergic neurons in cerebral cortex. Neuron 71:995-1013. CrossRef Medline

Tansey EP, Chow A, Rudy B, McBain CJ (2002) Developmental expression 
of potassium-channel subunit Kv3.2 within subpopulations of mouse hippocampal inhibitory interneurons. Hippocampus 12:137-148. CrossRef Medline

Tsai MS, Lee ML, Chang CY, Fan HH, Yu IS, Chen YT, You JY, Chen CY, Chang FC, Hsiao JH, Khorkova O, Liou HH, Yanagawa Y, Lee LJ, Lin SW (2015) Functional and structural deficits of the dentate gyrus network coincide with emerging spontaneous seizures in an Scnla mutant Dravet syndrome model during development. Neurobiol Dis 77:35-48. CrossRef Medline

Varga C, Golshani P, Soltesz I (2012) Frequency-invariant temporal ordering of interneuronal discharges during hippocampal oscillations in awake mice. Proc Natl Acad Sci U S A 109:E2726-E2734. CrossRef Medline

Wirrell EC, Laux L, Donner E, Jette N, Knupp K, Meskis MA, Miller I, Sullivan J, Welborn M, Berg AT (2017) Optimizing the diagnosis and management of Dravet syndrome: recommendations from a North American consensus panel. Pediatr Neurol 68:18-34.e3. CrossRef Medline
Wonders CP, Anderson SA (2006) The origin and specification of cortical interneurons. Nat Rev Neurosci 7:687-696. CrossRef Medline

Xue M, Atallah BV, Scanziani M (2014) Equalizing excitation-inhibition ratios across visual cortical neurons. Nature 511:596-600. CrossRef Medline

Yang JM, Zhang J, Yu YQ, Duan S, Li XM (2014) Postnatal development of 2 microcircuits involving fast-spiking interneurons in the mouse prefrontal cortex. Cereb Cortex 24:98-109. CrossRef Medline

Yang Y, Frankel WN (2004) Genetic approaches to studying mouse models of human seizure disorders. Adv Exp Med Biol 548:1-11. CrossRef Medline

Yu FH, Mantegazza M, Westenbroek RE, Robbins CA, Kalume F, Burton KA, Spain WJ, McKnight GS, Scheuer T, Catterall WA (2006) Reduced sodium current in GABAergic interneurons in a mouse model of severe myoclonic epilepsy in infancy. Nat Neurosci 9:1142-1149. CrossRef Medline 